$T N-1343$

Technical Note $\mathrm{N}-1343$

STANDARDIZED HARDWARE FOR OIL SPILL CONTAINMENT BOOMS

By

F. J. Campbell

June 1974

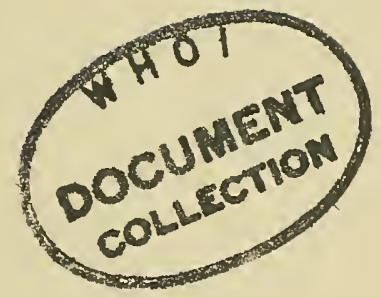

Naval Facilities Engineering Command

Alexandria, Virginia 22332

Approved for public release; distribution unlimited.

CIVIL ENGINEERING LABORATORY

Naval Construction Battalion Center

Port Hueneme, California 93043

TA

417

. NB

no, N 1343 

Unclassified

SECURITY CLASSIFICATION OF THIS PAGE (When Data Eniered)

\begin{tabular}{|c|c|}
\hline REPORT DOCUMENTATION PAGE & $\begin{array}{c}\text { READ INSTRUCTIONS } \\
\text { BEFORE COMPLETING FORM }\end{array}$ \\
\hline $\begin{array}{l}\begin{array}{l}\text { 1. REPORT NUMGER } \\
\text { TN }-1343\end{array} \text { 2. GOVT ACCESSION NO. }\end{array}$ & 3. RECIPIENT'S CATALOG NUMBER \\
\hline \multirow{2}{*}{$\begin{array}{l}\text { 4. TITLE (and Subtiffe) } \\
\text { STANDARDIZED HARDWARE FOR OIL } \\
\text { SPILL CONTAINMENT BOOMS }\end{array}$} & $\begin{array}{l}\text { 5. TYPE OF REPORT \& PERIOO COVEREO } \\
\text { Not final; Jan } 1973-\text { Dec } 1973\end{array}$ \\
\hline & 6. PERFORMING ORG. REPOAT NUMBER \\
\hline $\begin{array}{l}\text { 7. AUTHOR(s) } \\
\text { F. J. Campbell }\end{array}$ & 8. CONTRACT OR GRANT NUMBER(s) \\
\hline $\begin{array}{l}\text { 9. PERFORMING ORGANIZATION NAME ANO AODRESS } \\
\text { CIVIL ENGINEERING LABORATORY } \\
\text { Naval Construction Battalion Center } \\
\text { Port Hueneme, California } 93043\end{array}$ & $\begin{array}{l}\text { 10. PROG LAM ELEMENT. PROJECT. TASK } \\
\text { AREA A WORK UNIT NUMEERS } \\
65-111\end{array}$ \\
\hline $\begin{array}{l}\text { 11. CONTROLLING OFFICE NAME ANO AOORESS } \\
\text { Naval Facilities Engineering Command }\end{array}$ & $\begin{array}{l}\text { 12. REPORT DATE } \\
\text { June } 1974\end{array}$ \\
\hline Alexandria, Virginia 22332 & $\begin{array}{l}\text { 13. NUMBER OF PAGES } \\
58\end{array}$ \\
\hline 14. MONITORING AGENCY NAME \& AOORESS(rl dillerent trom Controlling Ollice) & $\begin{array}{l}\text { 15. SECUAITY CLASS. (ol this repart) } \\
\text { Unclassified }\end{array}$ \\
\hline & $\begin{array}{l}\text { 15. OECLLASSIFICATION'DOWNGAAOING } \\
\text { SCHEOULE }\end{array}$ \\
\hline
\end{tabular}

Approved for public release; distribution unlimited.

17. OISTRIBUTION STATEMENT (ol the abstract entered in Block 20, il dilferent Iram Report)

18. SUPPLEMENTARY NOTES

19. KEY WOROS (Cantinue on reverse side il necessary and identily by block number)

Hardware, containment booms, boom connector, towing assembly, boom-bulkhead attachment, oil spills.

20. ABSTRACT (Continue on reverse sjde it necessary and identily by block number)

This report describes the design, development, and testing of standardized hardware for use with existing and new Navy oil spill containment booms. This hardware which consists of boom connector, a towing assembly, and a boombulkhead attachment can be used to quickly interconnect and deploy oil booms of a wide variety of manufacturers.

DD, FORM 1473 EOITION OF INOVGSIS OBSOLETE

Unclassified

SECURITY CLASSIFICATION OF THIS PAGE (When Data Entered)

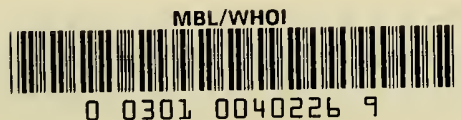




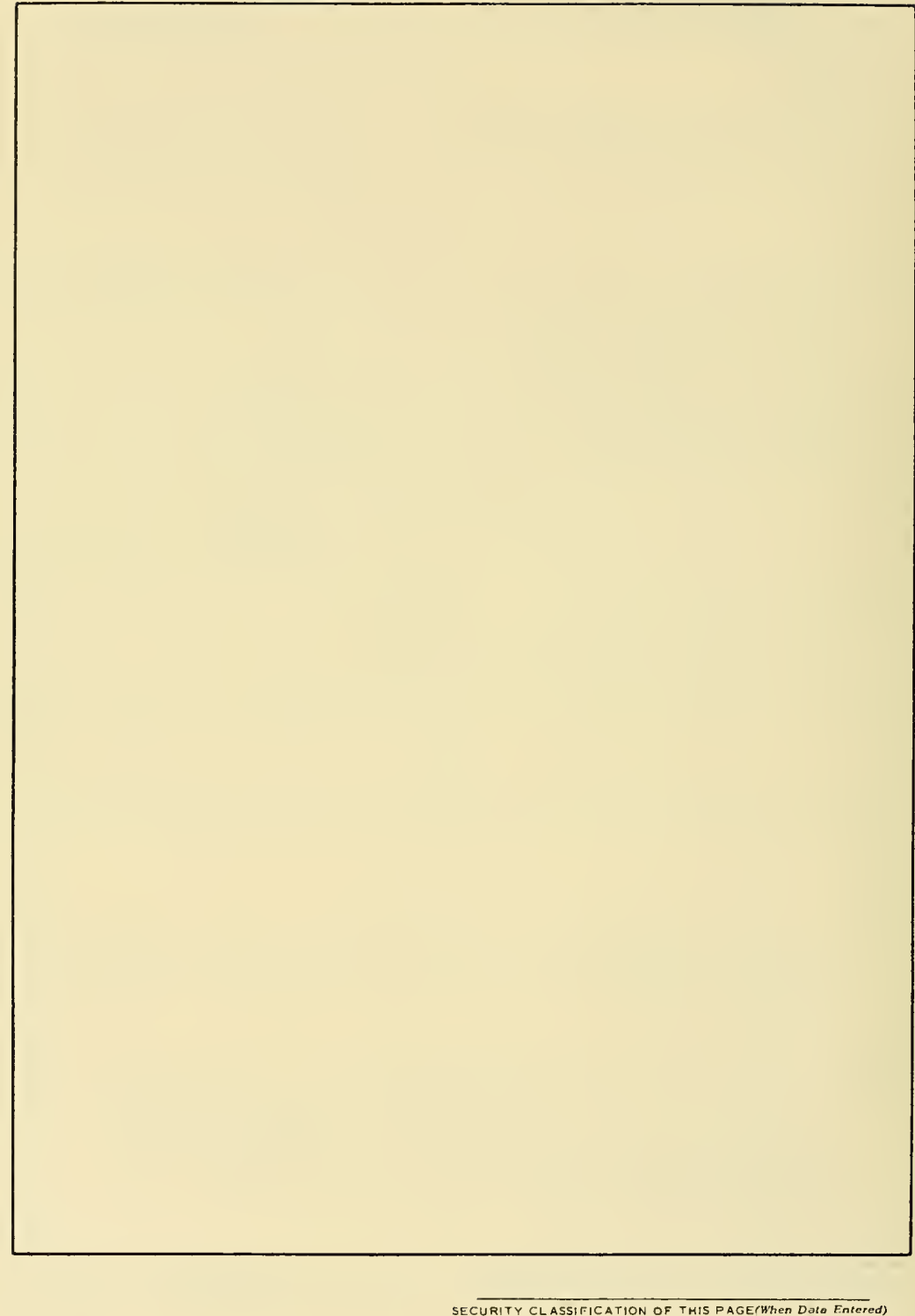

SECURITY CLASSIFICATION OF THIS PAGE(WhEN DOIO Entered) 


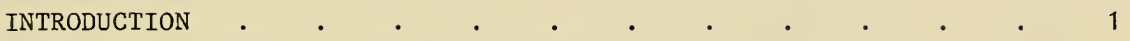

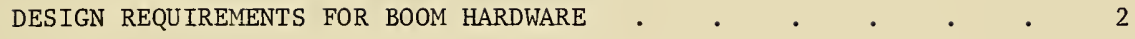

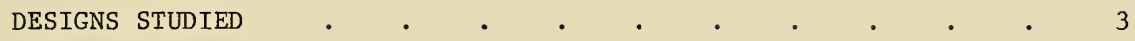

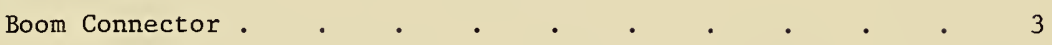

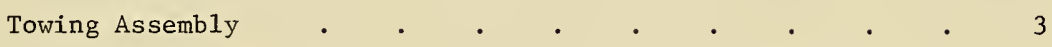

Bulkhead Attachment . $\quad . \quad$. $\quad . \quad$. $\quad . \quad 4$

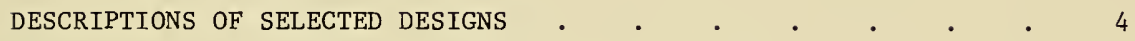

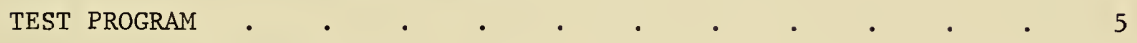

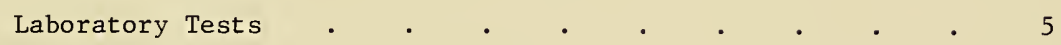

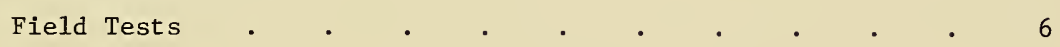

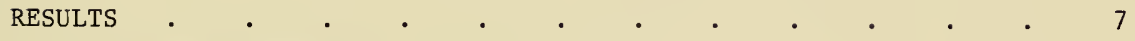

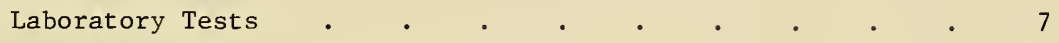

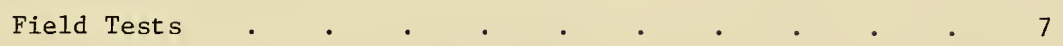

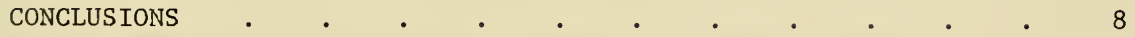

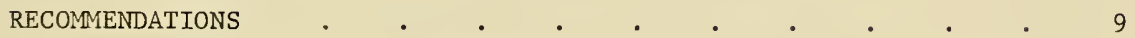

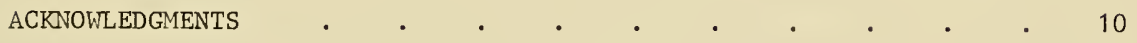

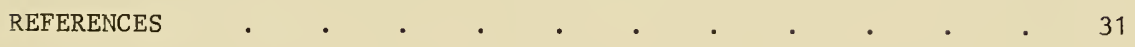

APPENDIXES

A - Hydrodynamic Forces . . . . . . . . . . 32

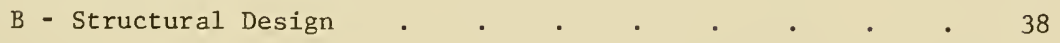


Figure 1. Boom-connector design candidates.

Figure 2. Towing-assembly design candidates. .

Figure 3. Bulkhead-attachment design candidate No. 1.

Figure 4. Bulkhead-attachment design candidate No. 2. .

Figure 5. Fabrication drawing of the selected boom connector.

Figure 6. Female (top) and male (bottom) boom connectors for joining sections of oil boom skirts.

Figure 7. Boom connectors locked together.

Figure 8. Fabrication drawing of selected boom towing assembly.

Figure 9. Towing assembly attached to boom.

Figure 10. Fabrication drawing of selected boom bulkheadattachment assembly.

Figure 11. Boom-bulkhead connector mounted on piling in harbor.

Figure 12. Boom connectors installed on oil boom skirts for Laboratory tests.

Figure 13. Boom connectors joining oil boom sections.

Figure 14. Two men in small boat assembling two oil boom sections by coupling boom connectors.

Figure 15. Completing coupling of boom connectors.

Figure 16. Towing 200 feet of oil boom in harbor.

Figure 1.7. Oil boom skirt attached to bulkhead in harbor.

Figure 18. Oil boom skirt and boom towing connector assembled for sea tests.

Figure 19. Towing oil boom at sea in straight-line configuration. 
Figure 20. Towing oil boom at sea in catenary configuration.

Figure 21. Calibrated tension unit installed at center of 1,000-foot boom.

Figure 22. Boom connector separation loads. . . . . . . 26

Figure 23. Straight-line towing forces in oil boom. . . . 27

Figure 24. Catenary towing forces in oil boom. . . . . . 28

Figure A-1. Shape of the pressure distribution on the submerged portion of the boom. . . . . . 34

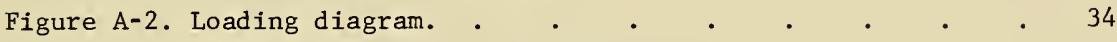

Figure A-3. Load model for sizing connectors. . . . . 34

Figure B-1. Boom connector loading. . . . . . . . . 46

Figure B-2. Structural sizing of candidates. . . . . . 47

Figure B-3. Boom-end clamping detail. $\quad$. . . . . . . 48

Figure B-4. Towing assembly loading diagrams. $\quad$. . . . 49

\section{LIST OF TABLES}

Page

Table 1. Comparison of proposed designs of boom connectors . . 29

Table 2. Comparison of proposed designs of the towing assembIy

Table 3. Comparison of proposed designs of bulkhead attachment.

Table A-1. Forces acting on 1,000 feet of boom under catenary tow. $. \quad . \quad . \quad . \quad$.

Table A-2. Forces acting on 1,000 feet of boom in straight tow. . . . . . . . . 



\section{INTRODUCTION}

Under various Federal laws and Executive Orders the Navy is responsible for cleaning up its own spills, and assisting with men and equipment as directed to provide salvage capability for any private or government vessel that poses a pollution threat. The Navy is concerned with developing its own oil-spi11-cleanup technology and capability because of the present lack of applied research and development of new procedures and hardware.

A 1969 study conducted by Battelle Memorial Institute, Pacific Northwest Laboratory, Richland, Washington, for the Civil Engineering Laboratory, * NCBC, Port Hueneme, California, disclosed that oil slicks were most effectively removed by the use of dispersants or by skimming the oil off. With dispersants banned except for use in hazardous spills, the Navy has pursued the development of better methods of physical removal. Rapid and effective containment of an oil slick by mechanical booms is of paramount importance to the successful removal of a spill. Therefore, one specific area of research is the design of more effective oil-containment booms.

The use of booms for passive containment, or as part of a recovery sweep system, requires well-designed and integrated boom components. Part of the Navy's problem has been the procurement of a wide variety of commercial oil-containment booms and, of course, the many new types of hardware associated with these booms.

Currently, each of the large number of oil-containment boom manufacturers has its own design for boom connectors and tow assemblies. Only a few have dock or bulkhead attachments available for use when the boom is deployed in areas with tidal fluctuations. A Naval field activity with more than one type of boom must fabricate special adaptors to interconnect booms of different sizes or to attach a boom to a dock or bulkhead. Equipment adaptation is further complicated when different Naval commands join forces to combat a major spill. In addition, much of the hardware has exhibited serious design deficiencies, especially in the area of structural strength. The Navy is correcting this situation by updating its Military Specification for oil-containment booms.

The problem of equipment incompatibility can be solved by developing:

1. A universal connector, which would allow sections of different types and sizes of boom to be connected.

* Formerly the Naval Civil Engineering Laboratory. 
2. A self-floating tow assembly, to provide easy attachment of tow cable during field use and to assure proper vertical loading of the boom end.

3. A bulkhead attachment, compatible with the universal boom connector and capable of maintaining a leak-proof seal at a dock or other vertical surface during vertical tidal variations.

CEL, sponsored by the Naval Facilities Command, undertook and completed the study of the designs, and then the development and testing of the above components.

DESIGN REQUIREMENTS FOR BOOM HARDWARE

Hydrodynamic forces experienced by a boom assembly during field use imposed restrictions on the design requirements of the boom connector and tow assembly. Appendix A discusses in detail the theoretical straightline and catenary hydrodynamic forces for the boom which had to be considered for any successful design of the hardware.

All three components (boom connector, tow assembly, and bulkhead attachment) were to be compatible with each other. In addition, the following characteristics were identified as being essential to the design of the standardized boom hardware.

The boom connector was to have the following characteristics:

1. Insensitivity to decoupling when subjected to surge and heave forces in the field.

2. Easy attachment by field personnel from small craft.

3. Rotational flexibility to reduce bending loads in bidirectional tidal currents.

4. Fabrication materials resistant to marine corrosion, easily extrusible, and with high strength.

The tow assembly was also to be fabricated from high-strength, extrusible, corrosion-resistant materials, as was the boom connector. In addition, the design was to include the following characteristics:

1. Enhanced damping of rol1 motion.

2. Good low-speed control of the towed boom end. 
3. Sufficient rigidity to resist the bending and buckling loads and yet be able to maintain vertical attitude.

4. Provision for proper towing load distribution over the vertical boom end.

Because boom-bulkhead attachments would be used primarily in confined harbor situations, the attachments were to have the following operational characteristics:

1. Easy adjustment to variations in water depth caused by tides.

2. Rotational flexibility about the track axis to minimize loads caused by bidirectional currents.

3. Bulkhead fitting to provide an oil-tight seal.

\section{DESIGNS STUDIED}

The structural requirements of the proposed designs, relating the size of components to the given materials, are analyzed in Appendix B. The design finally selected for development evolved from the information found in Appendix $A$ and $B$ and the findings from the study of the various hardware designs, as discussed below.

Boom Connector

Those designs considered in the CEL study for a universal boom connector to couple booms of different types and sizes* are shown in cross section in Figure 1. In each case, the boom end is clamped to the connector by means of a metal plate and bolts. All candidates have mounting holes for attachment of the primary tension member of a particular boom vendor. The boom end has a rod (flexible or rigid) running the full height of the boom to assist in keeping the connector attached to the boom under tensile loads. Each of the candidate designs shown have certain advantages and disadvantages which are tabulated in Table 1.

Towing Assembly

The two primary objectives of a separate towing assembly are the control of the towing load distribution over the boom height (depending upon the location of the primary tension member) and maintenance of the

* 12-inch (Type I, Class 1), 24-inch (Type I, Class 2), and 36-inch (Type II). 
boom in a vertical attitude during sweeping to minimize loss of oil under the boom. A secondary objective is to provide a single point for towing during field use. The two towing assembly candidates considered are shown in Figure 2. The advantages and disadvantages are presented in Table 2.

Bulkhead Attachment

Bulkhead attachment assemblies are needed to provide a leak-tight seal with a dock or other vertical surface during tidal variations. The assemblies may also be used to provide a load-carrying seal between a skimmer craft and the connecting boom. The two candidates for this component are shown in Figures 3 and 4 . Table 3 presents the advantages and disadvantages of the two designs.

\section{DESCRIPTIONS OF SELECTED DESIGNS}

All of the design candidates were determined to be structurally sound for the anticipated design loads. Therefore, the final selections of the recommended design from among the candidates was based upon the fulfillment of the design requirements for the boom hardware.

After review of the design candidates, the tubular assembly of the boom connector shown in Figure $1 \mathrm{~A}$ was selected as the basic unit for the assemblies, primarily because of its advantage over the other candidates in its insensitivity to decoupling and its rotational flexibility. Figure 5 is a dimensional sketch of the recommended design.

Several items are of interest in the final design of the boom connector hardware.

Aluminum alloy 6061-T6 was selected for al1 assemblies because of its high strength and good extrusion properties. The 5000 series of aluminum alloys has a higher marine-corrosion resistance but are much lower in yield strength than the 6000 series. With the 6061-T6 alloy the connector is strong enough to withstand forces which would be placed on the connector during operation, yet it is light and requires no buoyancy tanks. The extrusions are cut to fit the overall height of each type of boom size, and all corners in contact with the boom end are rounded to minimize abrasion (see Figure 5).

The female connector tapers outward and upward to a wider diameter at the top to allow insertion of the male connector without the disadvantage of aligning the two connectors in a vertical or nearvertical position. This makes it relatively easy to connect the sections in an open-sea situation.

If the female and male connectors are pulled apart, sufficient elasticity remains in the jaws of the female connector to permit reuse of the connector though subsequent failure would occur at lower tensile loads. 
A small retaining pin is used (see Figures 6 and 7) to prevent excessive relative vertical motion of the two sections of the connector.

A dacron line connected to the top of each connector makes them easier to lift out of the water when joining the boom connectors sections.

The self-floating towing assembly was recommended as shown in the dimensional sketch of Figure 8 . The assembly presented in Figure $2 \mathrm{~B}$ was not pursued because the use of a paravane-foot assembly to control the attitude of the towed boom end was considered impractical. The selected assembly is directly compatible with the male-connector section of the selected boom-connector assembly (Figure 5) and has a vertical plate near the bottom to assist in damping any roll motion (Figure 9). The towing assembly incorporates a female connector section welded to a single-tow-point float. It can easily be connected to or disconnected from deployed boom sections or a towing cable. Other advantages are its small size and its light weight.

The bulkhead-attachment design shown in Figure 10 fulfilled all of the requirements for the design. The same extrusion used for the boom connector was used for the sliding track. In this assembly, a femaleconnector section is welded to structural angle for attachment to a pier. Figure 11 shows the bulkhead attachment mounted on a piling in the harbor. A boom section can quickly be slid in or out of the top or bottom of the attachment.

It should be noted that the extrusion for the larger concentric tube (female connector) can be used for the bulkhead-attachment assembly on a towing vessel or oil skimmer so that a boom end supplied with the male extrusion can be connected directly to the towing assembly.

\section{TEST PROGRAM}

Prototypes of the boom connector, towing assembly, and bulkhead attachment were fabricated and subjected to an accelerated series of laboratory and field tests. These tests were designed to establish the adequacy of the prototype standardized boom hardware for its intended use and to verify the assumptions used in the design of the hardware. Laboratory tests determined the strength of the connectors and simulated conditions where leakage of oil could occur. Field tests simulated the force loadings and handling situations that would be encountered in actual field use. Thus, any necessary modifications to the assemblies were implemented before the equipment was put into field service.

\section{Laboratory Tests}

The laboratory tests, restricted to testing of the male and female boom connector, were conducted on a tensile test machine and in a small-wave tank, and quantitative and qualitative observations 
were recorded. Three connector lengths (6, 12, and 18 inches) were subjected to tensile tests to determine whether the structural design requirements (see Appendix B) were met.

The strength required to separate the male and female connectors was measured. Failure occurred when the inner (or male) connector pulled out of the outer (or female) connector (see items 5 and 6 in Figures 6 and 7 ). The male connector bore against the outer ends of the female connector, thus springing the female connector open. After the tests, however, only a small permanent expansion was noted in this connector.

The connector sections were also tested for oil leakage at the area where they were joined (see Figure 12). In these tests for leakage, current speeds of 0.01 knot and 0.25 knot and a wave height of 2.7 feet were produced in the tank. Heavy and light weights of oil were used in the tests: 90-weight gear lube and 10 weight hydraulic oil, respectively.

\section{Field Tests}

All of the prototype hardware were field-tested to identify any operational faults in their design.

Harbor Tests. The boom-connector prototype was first tested for the ease with which two 3-foot connector sections, compatible with Type II boom, could be joined. The connector was installed on a 46-inch deep Kepner boom (Figure 13). A total length of 1,000 feet was available: two sections each 200 feet long and two sections each 300 feet long. The time required for two men in a small boat to join two sections of the boom together was measured (Figures 14 and 15): the connectors were easily joined together in 30 seconds.

The towing assembly was checked for ease of connection to a boom section. Then straight-line towing stability tests were conducted, using short lengths (200 and 400 feet) of boom (Figure 16) at tow speeds of $1,2,3$, and 4 knots. The nylon towline length was 90 feet. The 400-foot oil-boom skirt tended to weave during the tow but did not turn on its side; however, the 200-foot length did turn on its side during the tests.

The 10-foot-long bulkhead-attachment assembly was fabricated and positioned on a pier piling in the harbor for the assembly to accommodate 6-foot tidal changes. During fabrication the assembly warped when the female connector was welded to the aluminum angle. A 200-foot section of Kepner oil boom was attached to the assembly to determine the ease in connecting the two pieces of male and female connectors together (Figure 17). The boom section was left connected to the bulkhead assembly for 6 hours and followed tidal variations with no difficulty.

Open Sea Tests. The Kepner boom sections were joined together to form a 1,000-foot length which was towed to sea in a straight line (Figures 18 and 19). At sea, a second boat attached a line to the free 
end of the boom-towing assembly and formed a catenary with the first tow boat (see Figure 20). A 300-foot interval was maintained between the two boats and tow speeds of $0.2,0.6,0.8,1.0$ and 1.1 knots were established. Swells were 3 to 4 feet in height, and winds were 5 knots from the starboard quarter.

Measurements were taken of the tensile force developed in the center connector and in both towing cables. A calibrated tension unit (Figure 21) was mounted between the center boom connectors to measure the load at this location. The skirt tended to overturn and plane at a speed over 0.8 knot. At a speed of 1.1 knots the skirt tended to plane at the center of the catenary, and water spilled over the boom. At times the towing assembly tended to submerge during tow. A post-test inspection of the nuts and bolts used to hold the boom to the connectors showed they were galling and had siezed together.

\section{RESULTS}

\section{Laboratory Tests}

Figure 22 contains results of the load tests that were conducted on the 6-, 12-, and 18-inch lengths of boom connectors. The load required to separate the connectors is predicted to be 13,500 pounds for the Type I Class 1 connector, 29,000 pounds for the Type I Class 2 connector, and 43,000 pounds for the Type II connector.

In the oil-leakage tests, approximately 0.04 pint per hour leaked through the boom-connector joint when a $0.25-k n o t$ current applied tension on the joint. As the tension on the boom connector was reduced to $0.01 \mathrm{knot}$, the leakage through the joint increased to an estimated 0.5 pint per hour.

\section{Field Tests}

The measured straight-line towing loads for different lengths of booms and towing speeds and the theoretical towing loads predicted in Appendix A are shown in Figure 23. The largest load measured was 1,450 pounds which was recorded when 1,000 feet of boom was towed at 5 knots.

The average tensile loads in the one towing cable (recorded when 1,000 feet of boom was being towed in a catenary configuration at different speeds) is shown in Figure 24. The largest tow load, 1922 pounds, was measured when the boom was being towed at 1 knot. Beyond this speed the boom used in the tests turned on its side. Booms that do not turn on their sides at these and higher speeds would place a greater load on the towing cables and connectors. Loads recorded at the center of the 
boom when it was heing towed in a catenary configuration ranged from 500 pounds at $0.2 \mathrm{k} \cdot n t$ to 1,455 pounds at 1.1 knots $(1,455$ pounds is considered low as the boom had turned on its side at 1.1 knots).

The measured catenary tow loads and the loads predicted by the theoretical analysis in Appendix A are shown in Figure 24.

\section{CONCLUSIONS}

1. The boom connectors satisfactorily held the boom-skirt section together and were simple and easy to connect, even while two men worked from a small boat.

2. The towing assembly provided a satisfactory method of towing the oil boom in straight-line and catenary-tow configurations. This assembly was easily connected to and disconnected from the connectors on the oil boom.

3. The boom-bulkhead connector assembly was easily installed on a pier piling. An oil boom was quickly attached to the bulkhead connector, and the connector allowed the attached boom to follow tidal variations.

4. The boom towing loads measured during field tests confirmed the validity of the theoretical towing load predictions, Appendix A, that were used in the initial design of the hardware.

5. Oil did not leak through the hinge area of assembled connectors when a sufficient, and normally present, tensile force was applied to the connector. Oil leakage, which occurred when a sufficient tensile force was not present, was not significant; and a special gasket was not needed.

6. Galling and siezing of the bolts and nuts used to hold the oil boom to the boom connectors was due in part by the use of fine screw threads for the items. Coarse screw threads should be used instead.

7. The number $5-44 \mathrm{NF}$ round-head screws used in the connector assemblies stripped the threads tapped in the connectors because of the relative softness of the aluminum connector compared to the steel screw and the small size and therefore low strength of fine screw threads used. A larger screw with coarse threads would not strip the aluminum threads as easily.

8. The towing assembly submerged at times during the field tests because the towing load created a force couple in the assembly which could not be counteracted until the front end of the assembly submerged. This force couple could be counteracted by lowering the location of the tow hole on the assembly. 
9. During field tests the towing cable chafed against the towing assembly because the shackle used to hold the cable to the assembly was too small to allow sufficient clearance. A larger shackle would prevent this problem.

10. Warping of the bulkhead assembly, which occurred during fabrication, was caused by the use of continuous filet welds to join the female connector to the aluminum angle section. The use of staggered filet welds would prevent warping.

\section{RECOMMENDATIONS}

1. The boom end connectors, towing assembly, and bulkhead-attachment assembly, modified as recommended below, should be procured and used as part of the Navy's oil-spill-containment program. An effort should be made to extend the use of this hardware to other Federal agencies and possible commercial users to reduce procurement costs and to prevent the occurrence of equipment incompatibilities in the future when these agencies join forces to combat an oil spill. A patent application which covers the end connectors, towing assembly, and bulkhead attachment has been filed and should be processed by the appropriate Navy agencies.

2. Alternative pier mounting configurations should be developed for the bulkhead-attachment assembly. The configuration used in the tests permitted the assembly to jut out from the piling where it could potentially cause damage to small craft and ships that came in contact with it.

3. Field activities that use these connectors should be instructed to take several sets of unmounted male and female connectors and bolt two male or female connectors together back to back. Situations will occur during field use where identical and therefore incompatible connectors must be joined together. (These extra sets of connectors (both male if the incompatible connectors are female, or vice versa) can be used to join the incompatible connectors together.)

4. The drawing modifications recommended in No. 2 through 7 above have been incorporated into the final fabrication drawings (Figures 5, 8, and 10) used for the procurement of the hardware as part of the Fiscal Year 1974 oil-boom procurement program.

a. The number 3/8-24NF nuts and bolts used in the tests to attach the oil boom to the connectors should be changed to number 3/8-16NC nuts and bolts, and these parts should be coated with an antisieze compound to prevent galling and siezing. 
b. Number 6-32NC round-head bolts should be substituted for number $5-44 \mathrm{NF}$ bolts. The coarser threads of this bolt will decrease the probability of stripping aluminum screw threads.

c. The towing hole of the towing assembly should be lowered 2 inches vertically to keep the front of the assembly from submerging when it is towed.

d. Polyurethane foam should be placed inside the float of the towing assembly to prevent the assembly from sinking if damage should occur to the float section.

e. The female connector of the bulkhead-attachment assembly should be attached to the angle section with 3 -inchlength filet welds spaced on 6 -inch centers and staggered on opposite sides. This method will prevent the assembly from warping during welding.

f. A 3/4-inch shackle should be substituted for the 5/8-inch shackle used in the tests. The larger shackle will give sufficient clearance between a towing cable and the towing assembly. The thickness of the bosses that are welded to the tow hole should be increased from $1 / 4$ inch to $5 / 16$ inch to maintain proper clearance between the shackle and the bosses.

\section{ACKNOWLEDGMENTS}

Mr. D. J. Graham for developing the overall conceptual designs and sizing the prototype bulkhead attachment and towing assembly.

Dr. J. J. Der for performing the analysis of boom towing forces (Appendix A).

Mr. E. P. Skillman for assisting in the structural analysis of connectors.

Mr. Kit L. Mack for developing the drawings of Figures 5, 8 and 10 .

$\mathrm{Mr}$. R. C. Towne and Mr. R. A. Bliss for the execution of the laboratory and field tests.

$\mathrm{Mr}$. C. Quigley and G. S. Duffy for the instrumentation required in the laboratory and field tests.

Mrs. V. N. Spafford for compiling much of the material in this note and putting it in a readable form. 

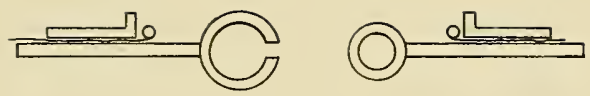

A
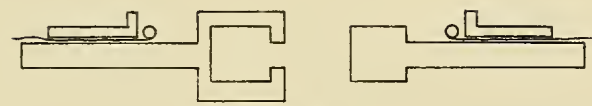

B
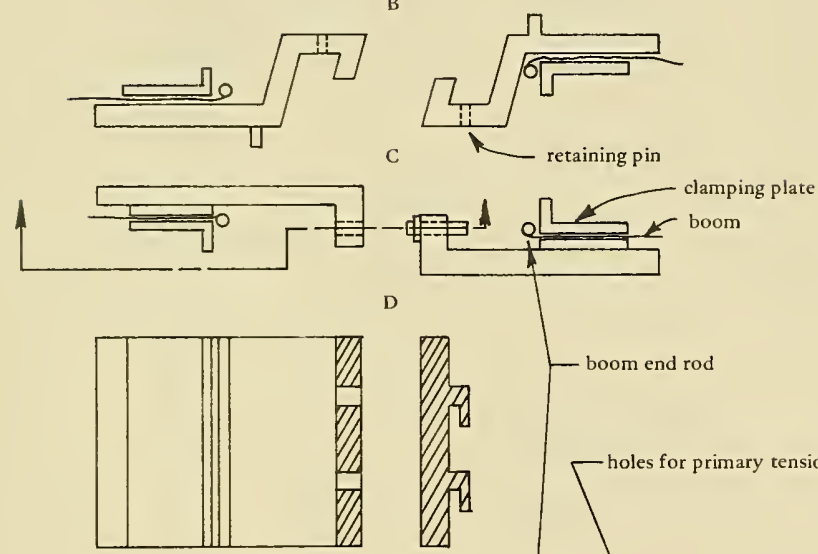

D
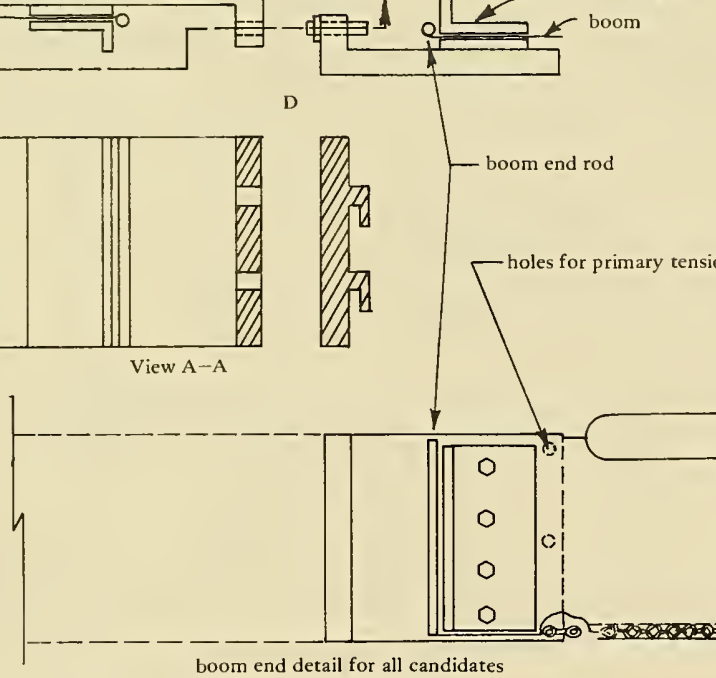

boom end rod

Choles for primary tension member(s)

boom end detail for all candidates

Figure 1. Boom-connector design candidates. 

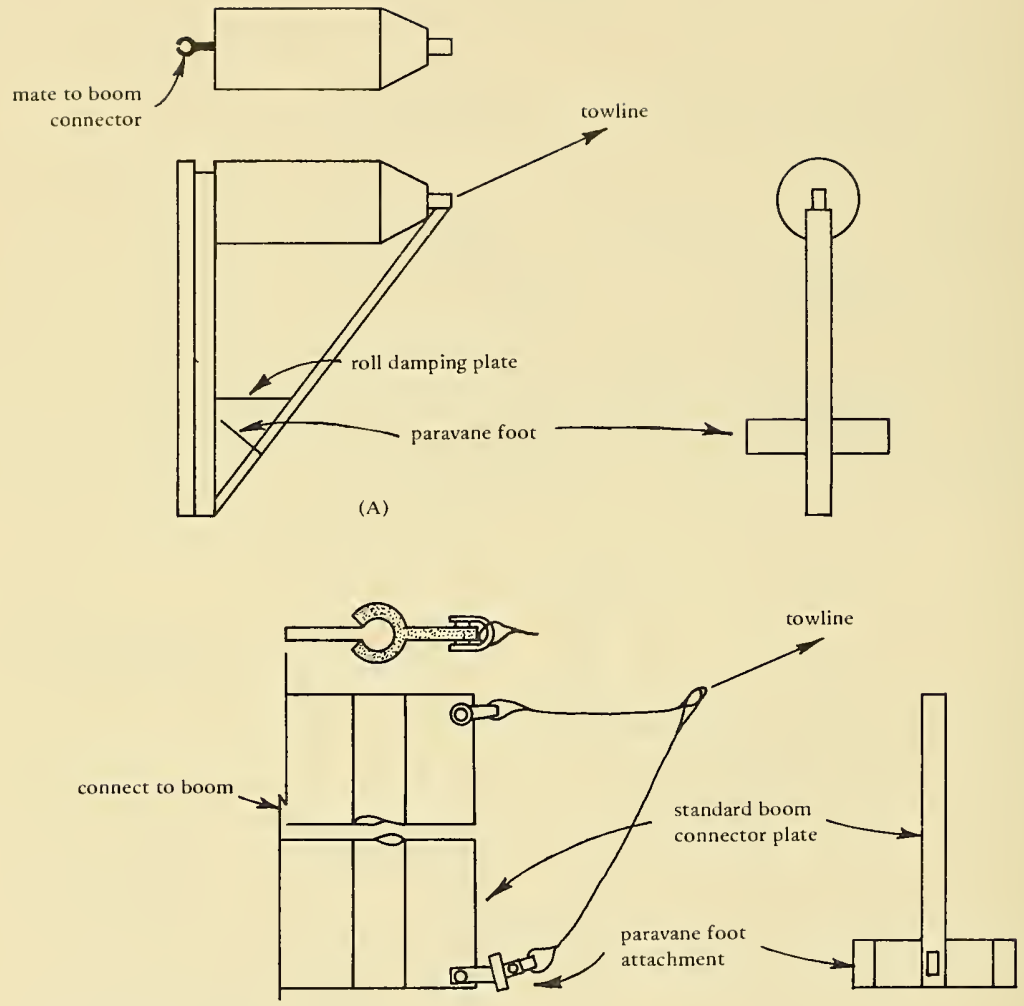

(B)

Figure 2. Towing-assembly design candidates. 

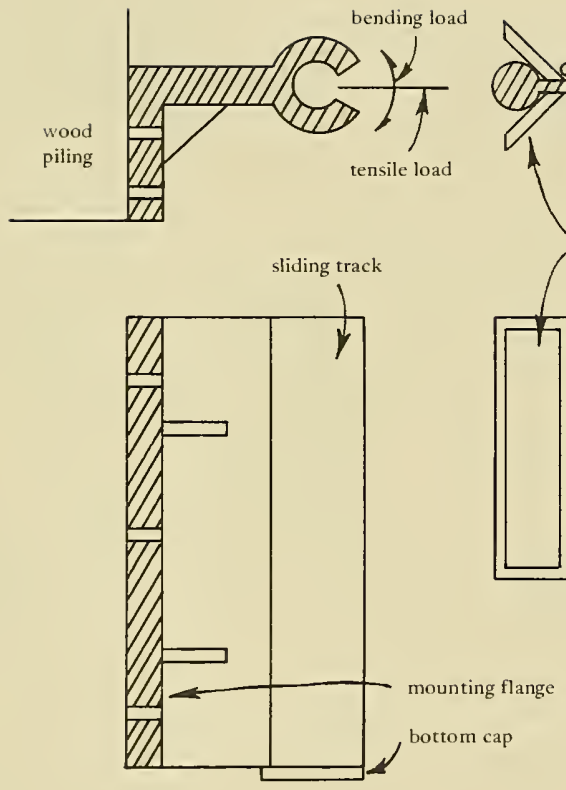

Figure 3. Bulkhead-attachment design candidate No. 1. 


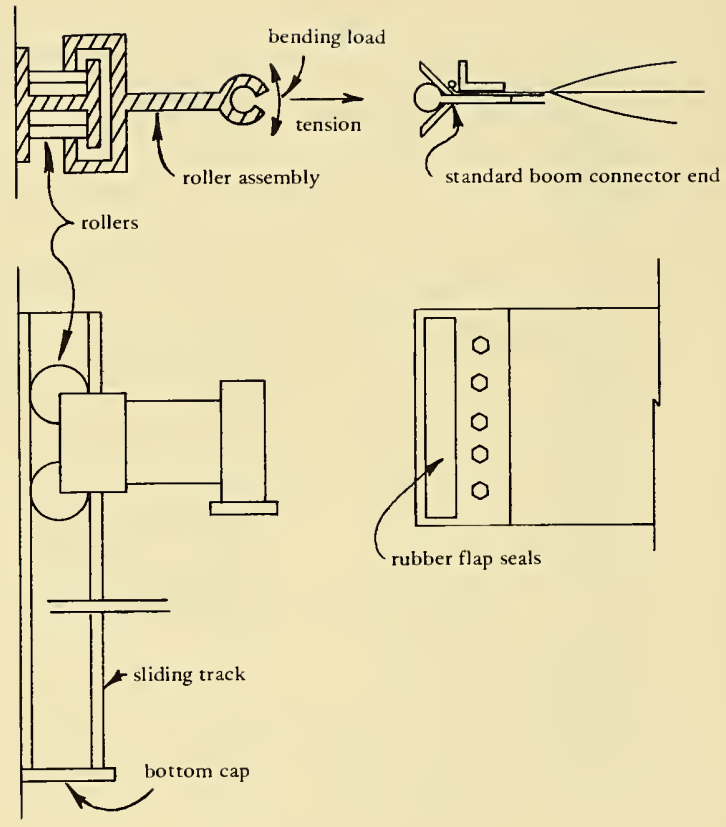

Figure 4. Bulkhead-attachment design candidate No. 2. 


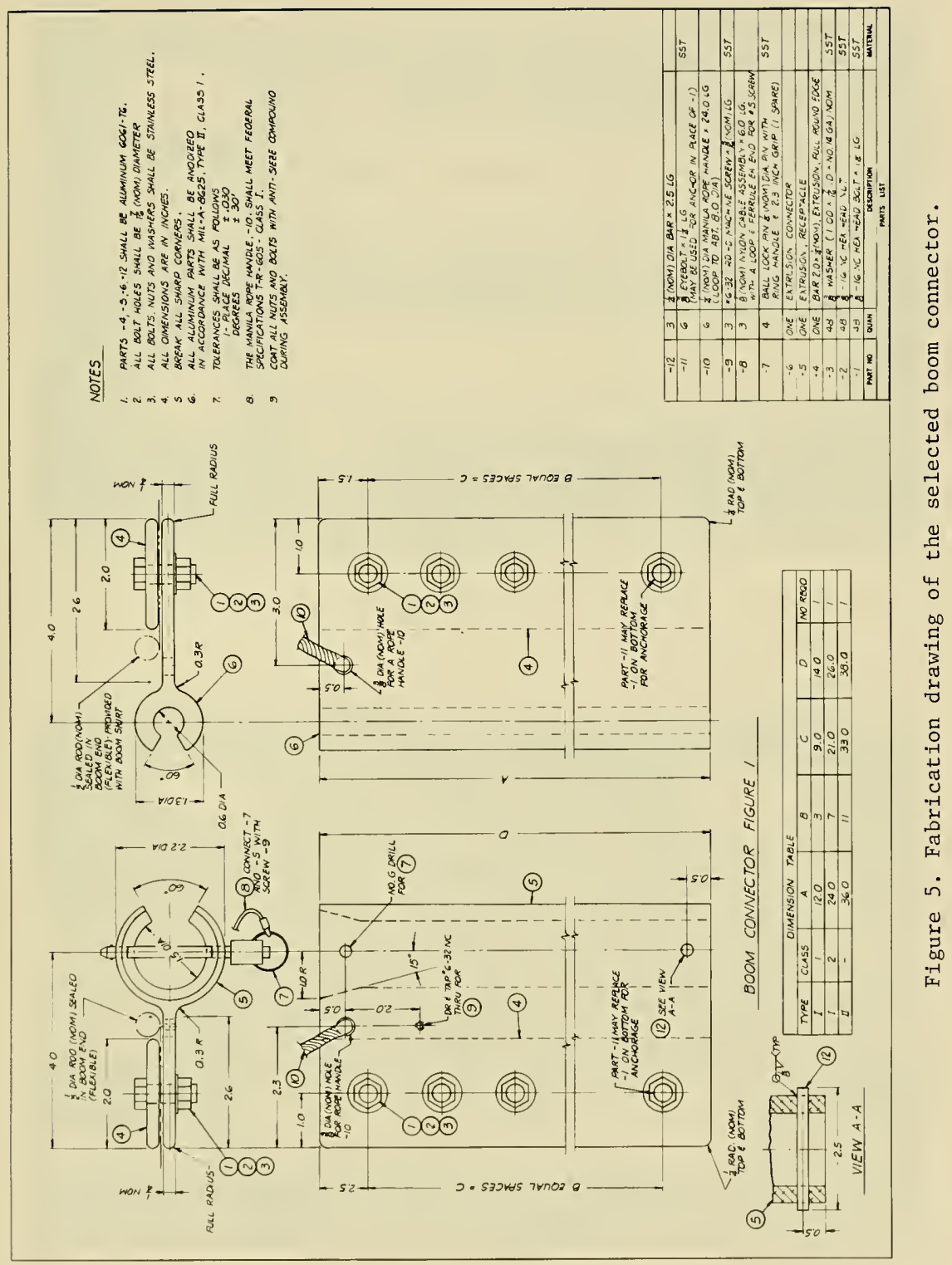




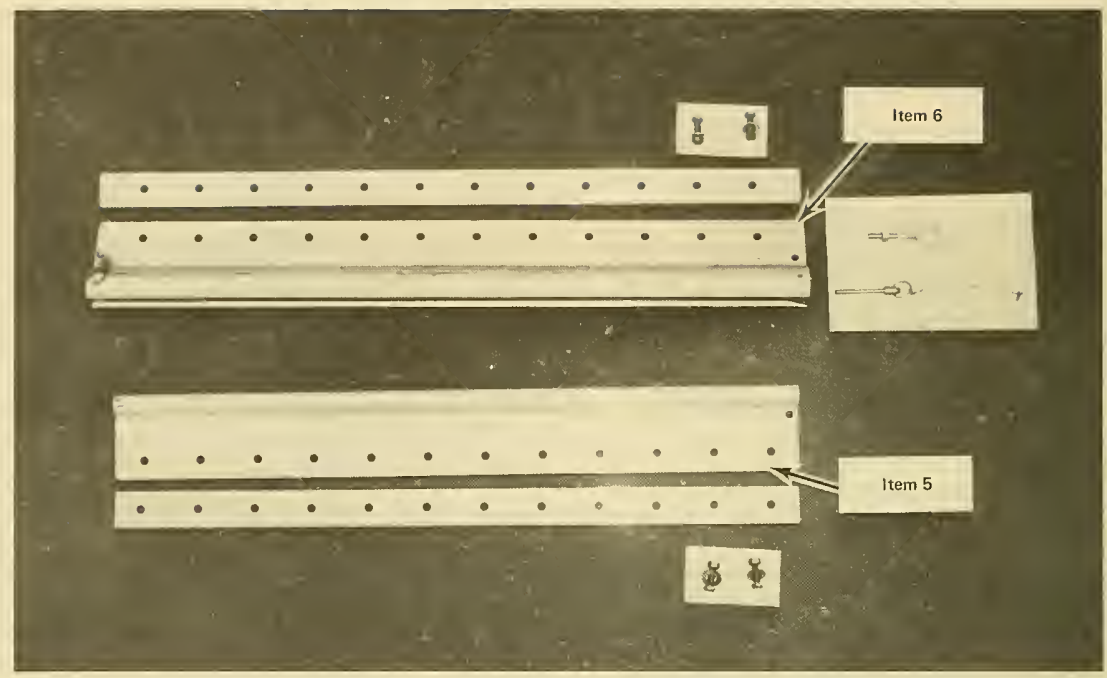

Figure 6. Female (top) and male (bottom) boom connectors for joining sections of oil boom skirts.

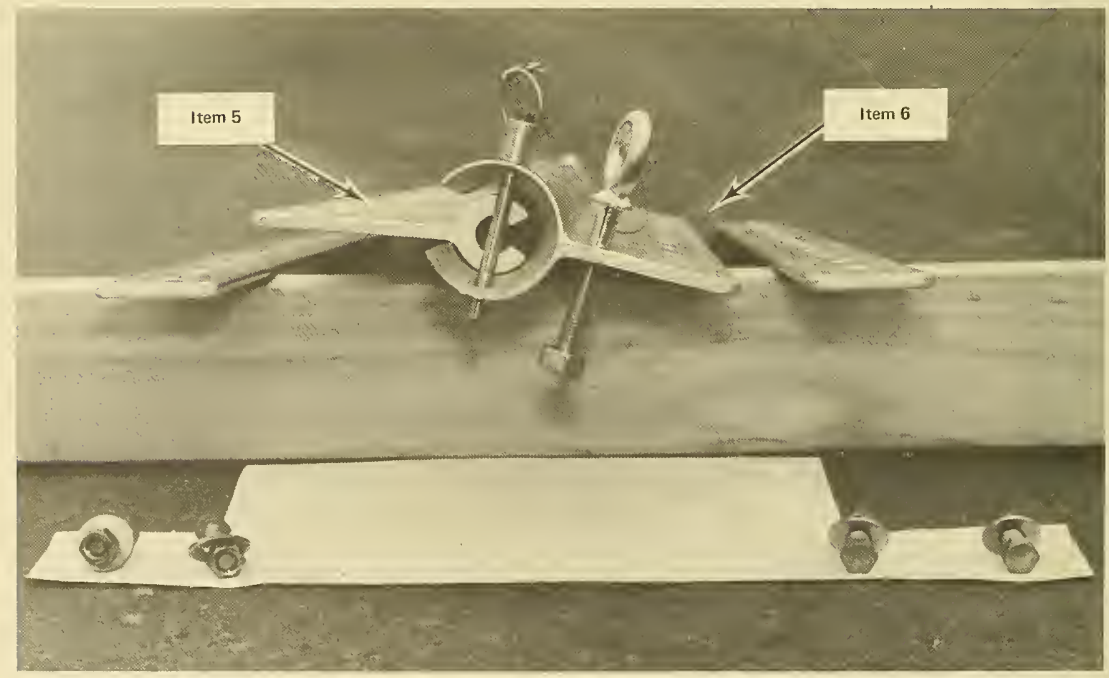

Figure 7. Boom connectors locked together. 


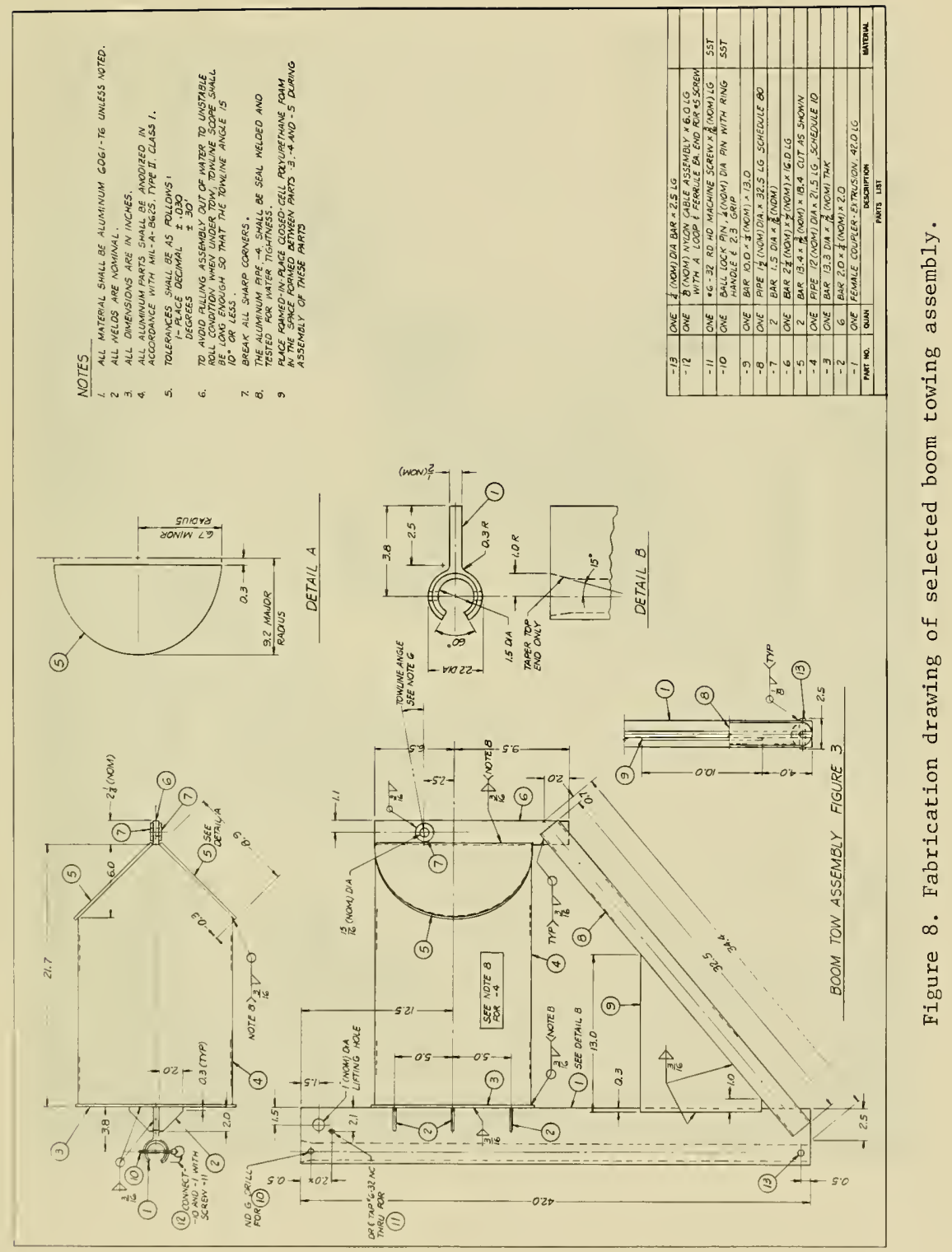




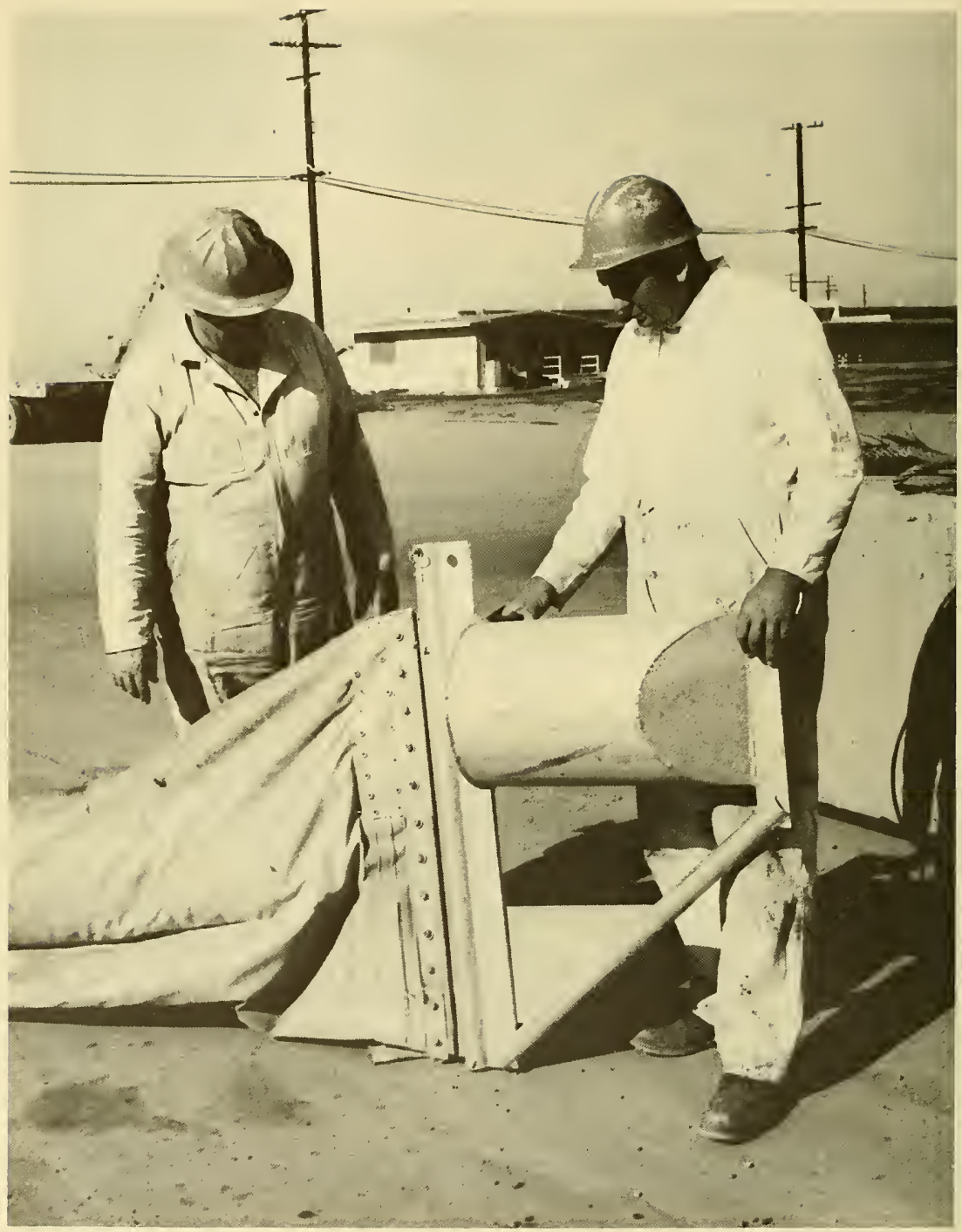

Figure 9. Towing assembly attached to boom. 


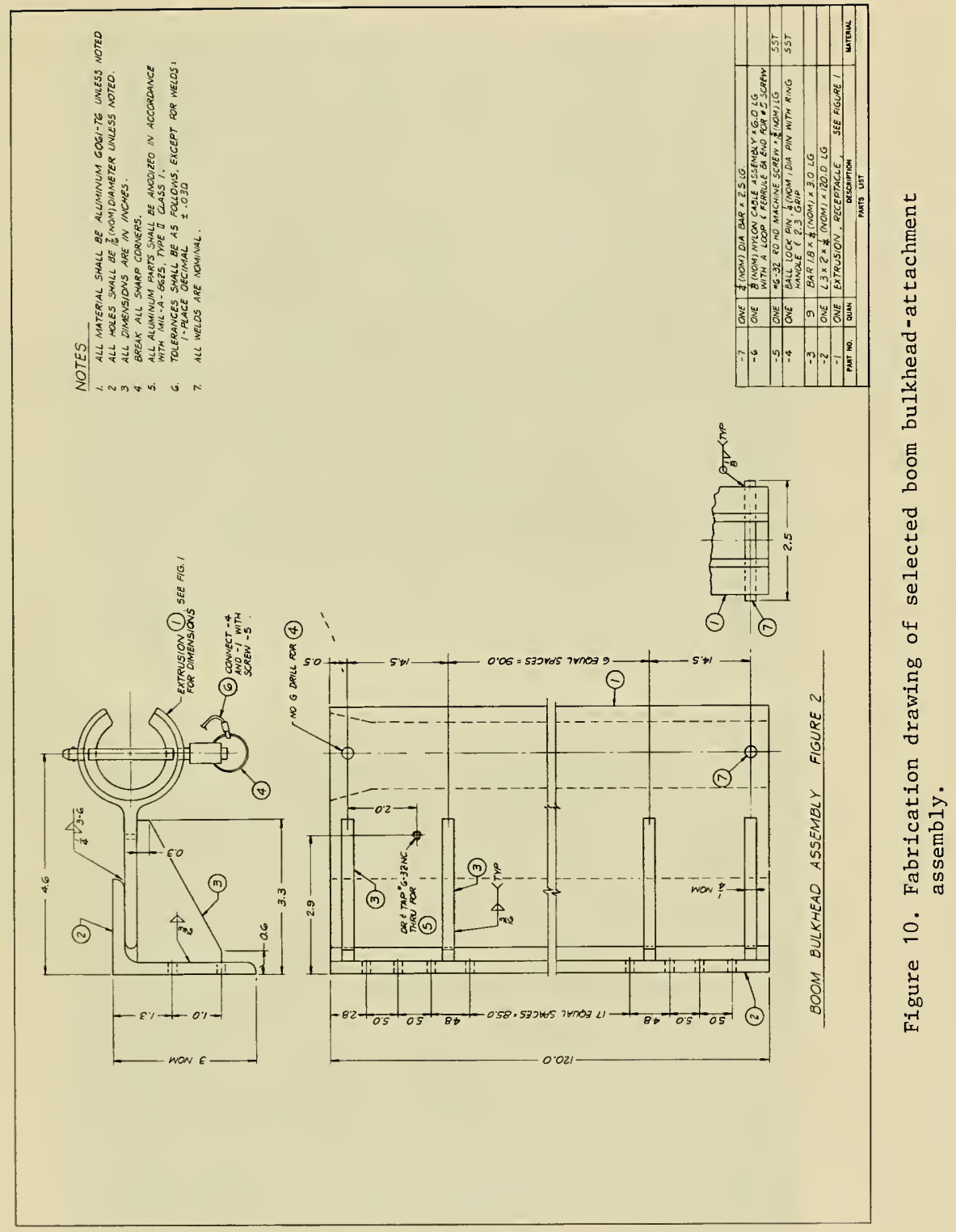




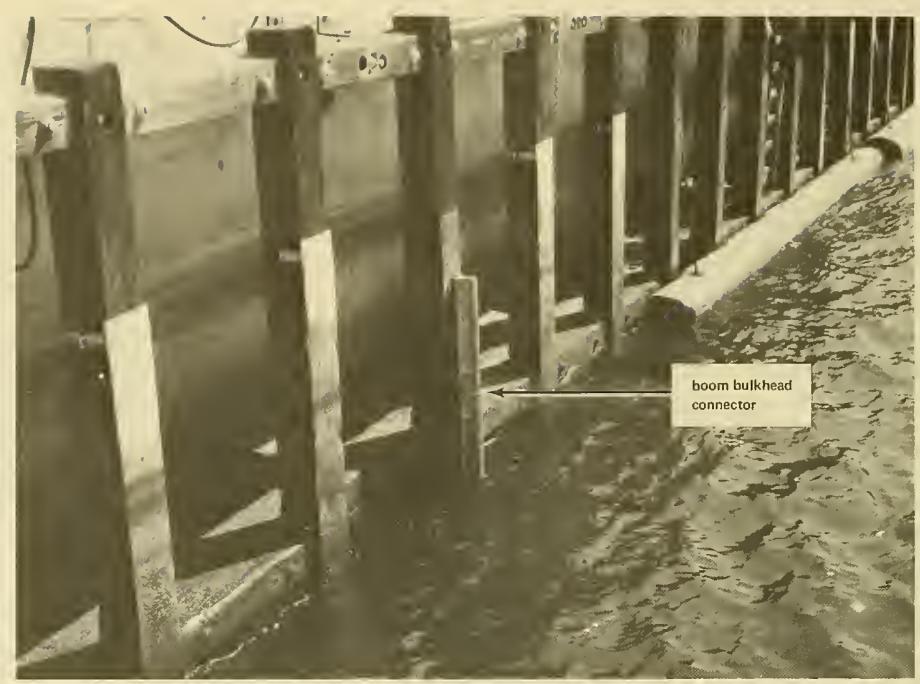

Figure 11. Boom-bulkhead connector mounted on piling in harbor.

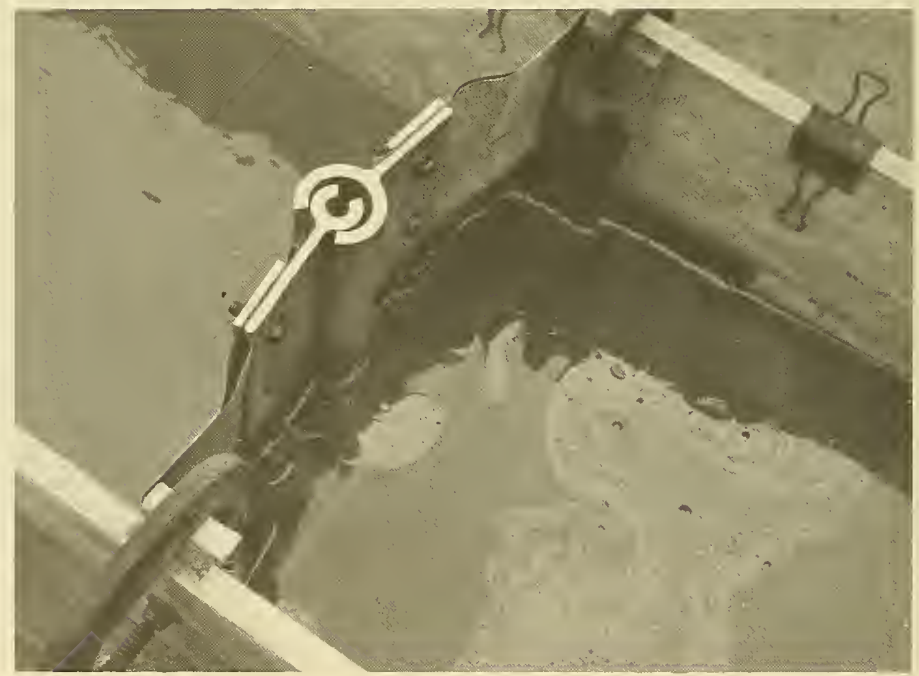

Figure 12. Boom connectors installed on oil boom skirts for Laboratory tests. 


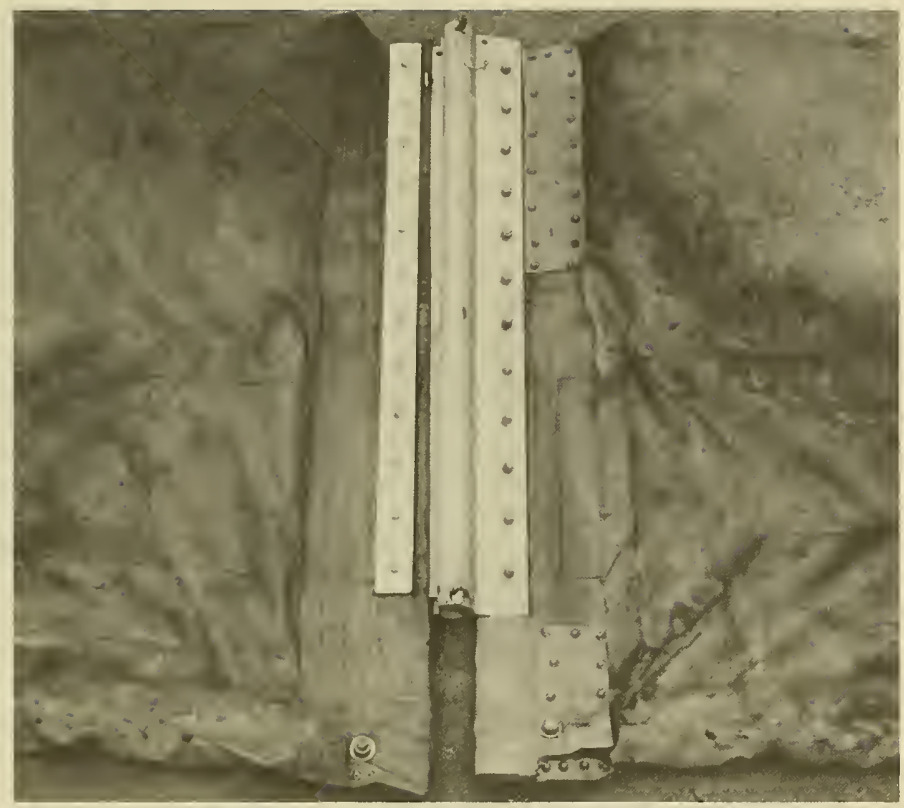

Figure 13. Boom connectors joining oil boom sections.

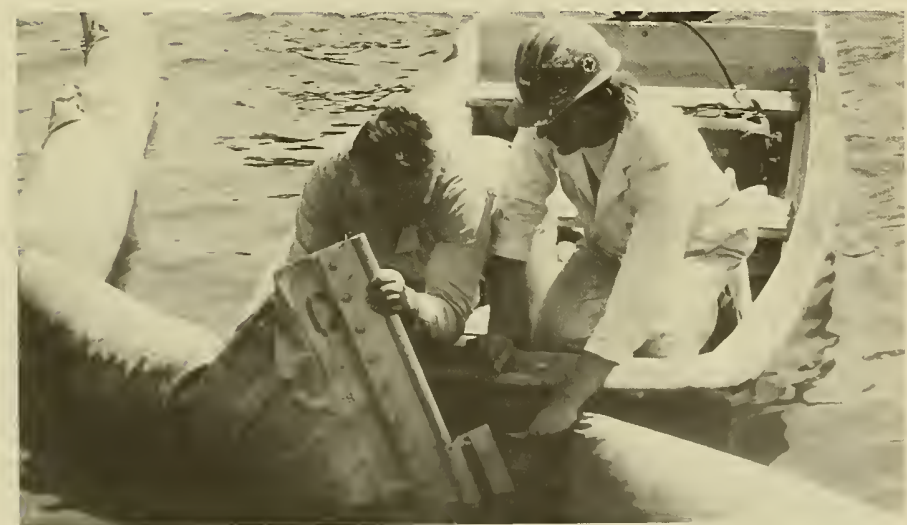

Figure 14. Two men in small boat assembling two oil boom sections by coupling boom connectors. 


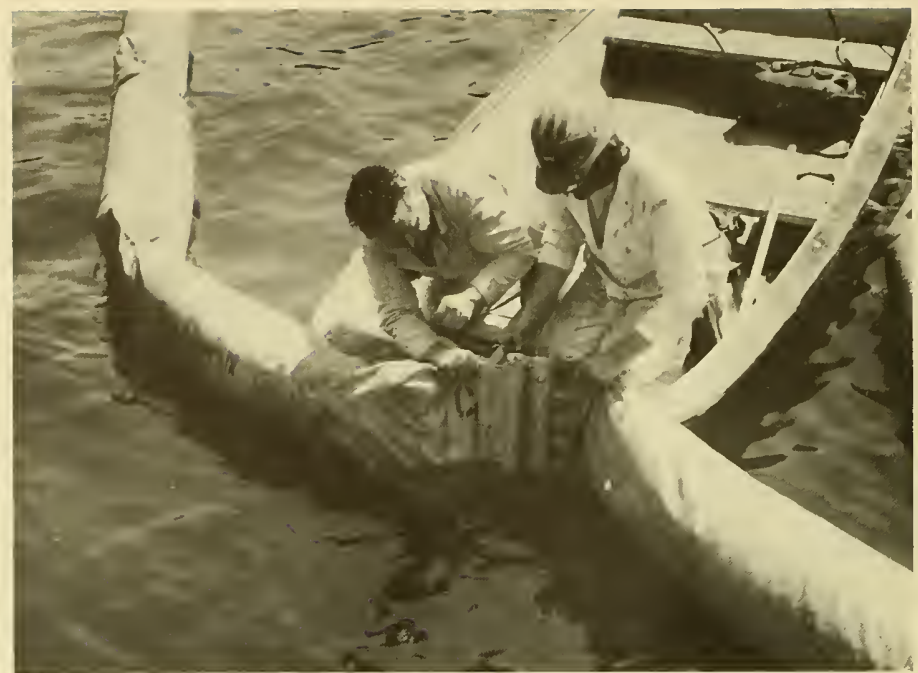

Figure 15. Completing coupling of boom connectors.

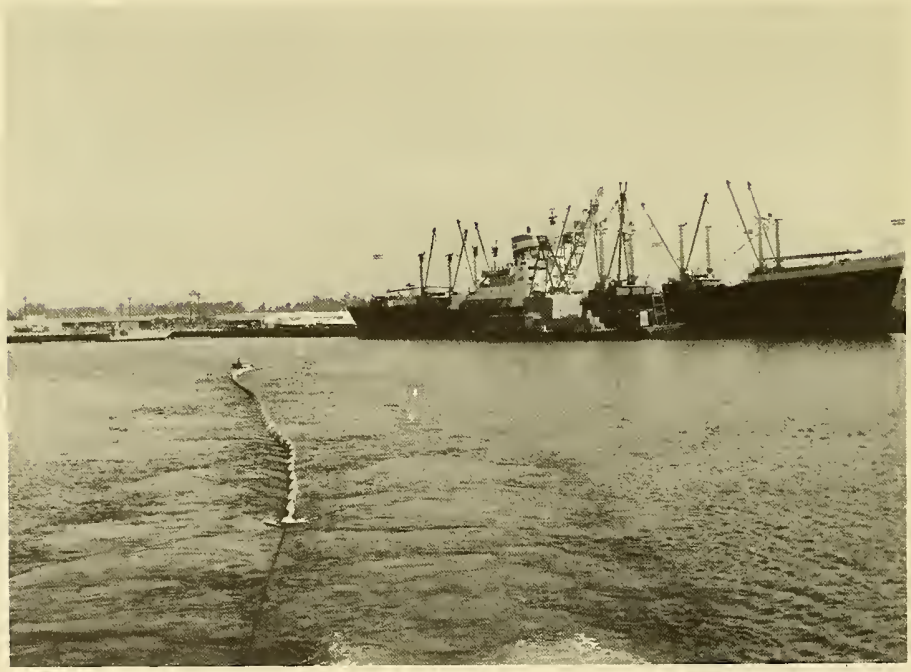

Figure 16. Towing 200 feet of oil boom in harbor. 


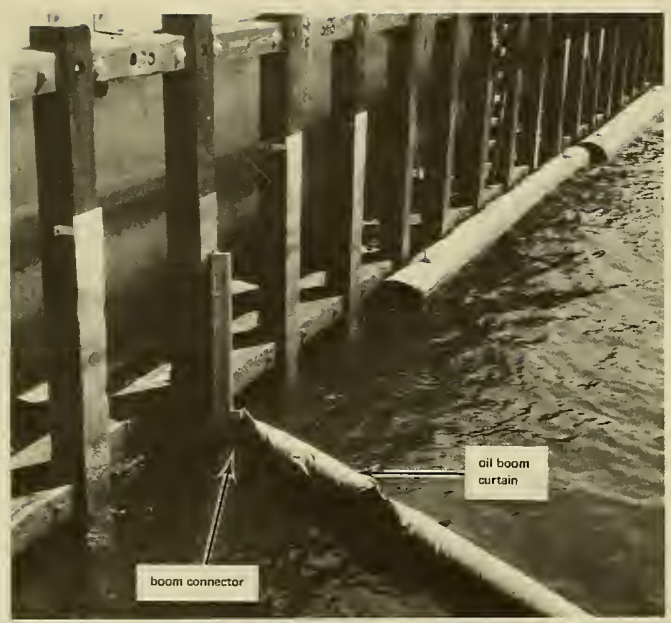

Figure 17. Oil boom skirt attached to bulkhead in harbor.

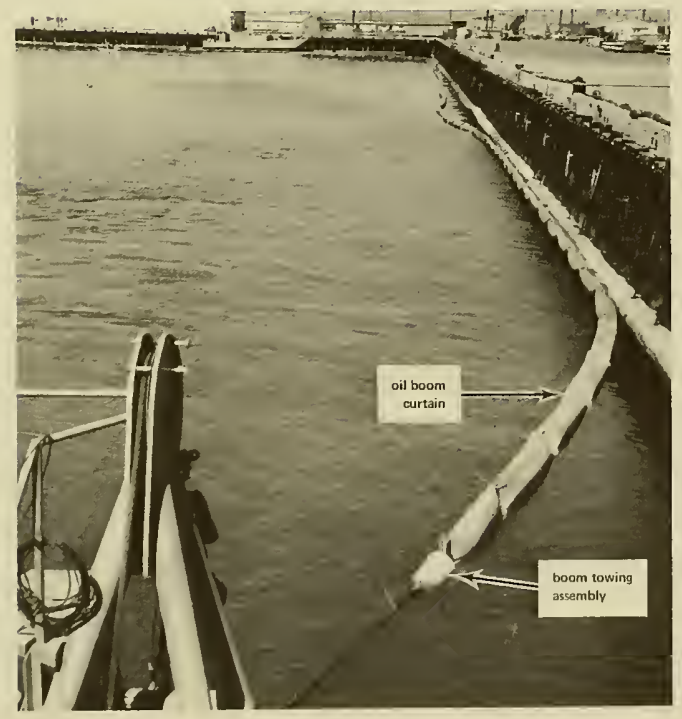

Figure 18. Oil boom skirt and boom towing connector assembled for sea tests. 


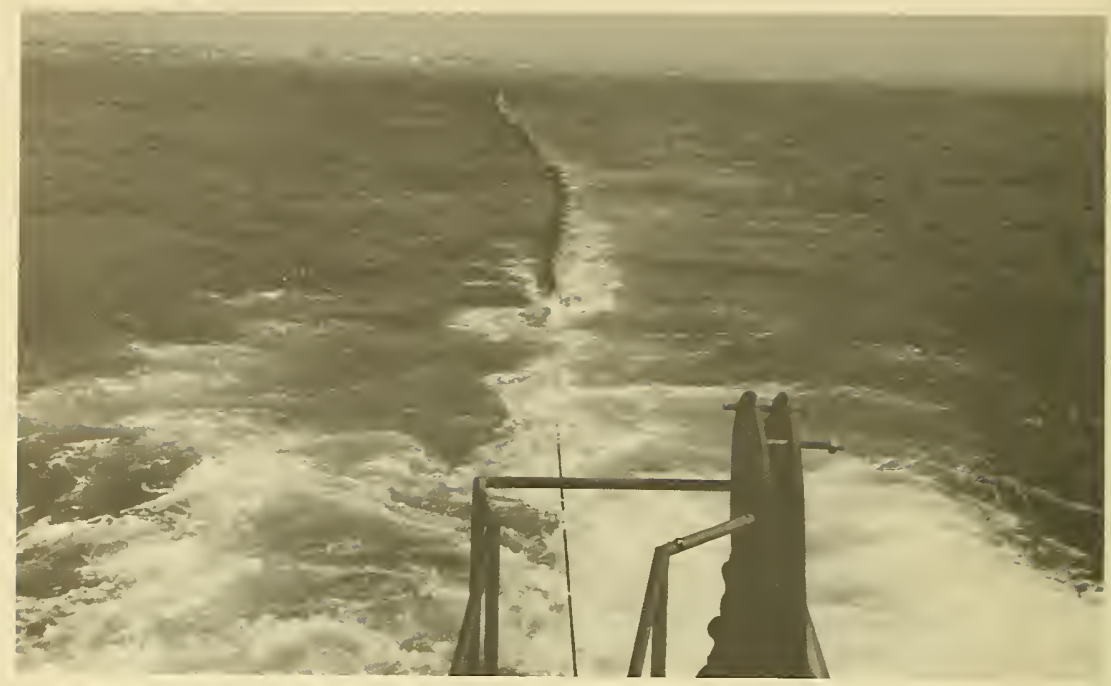

Figure 19. Towing oil boom at sea in straight-line configuration.

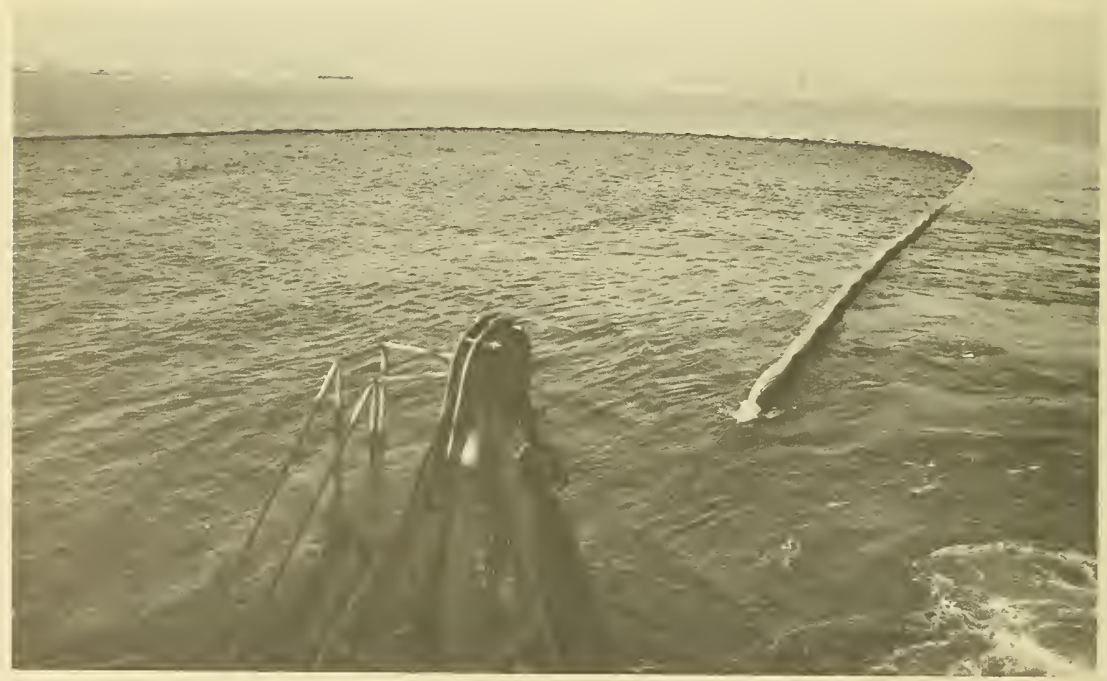

Figure 20. Towing oil boom at sea in catenary configuration. 


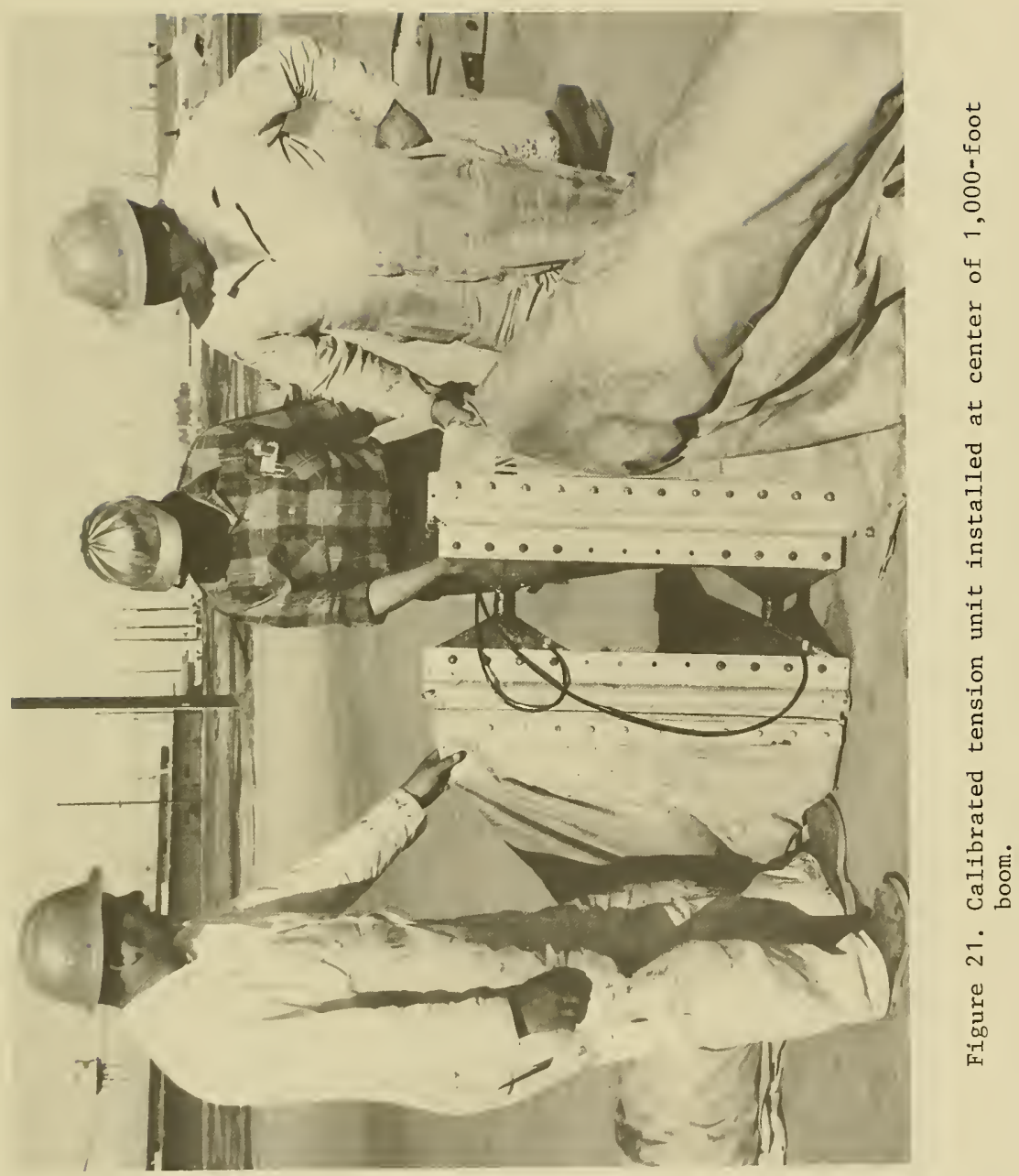




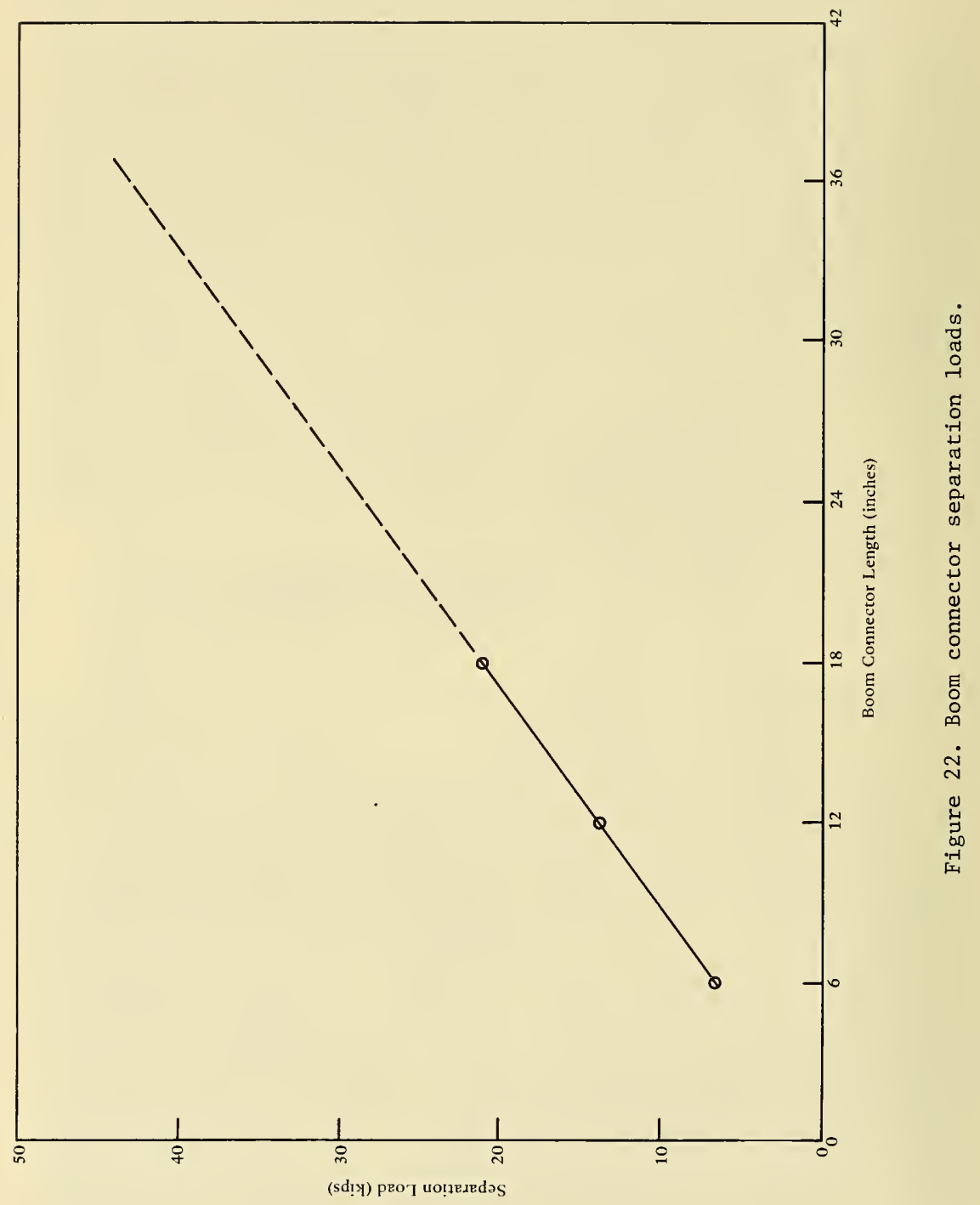




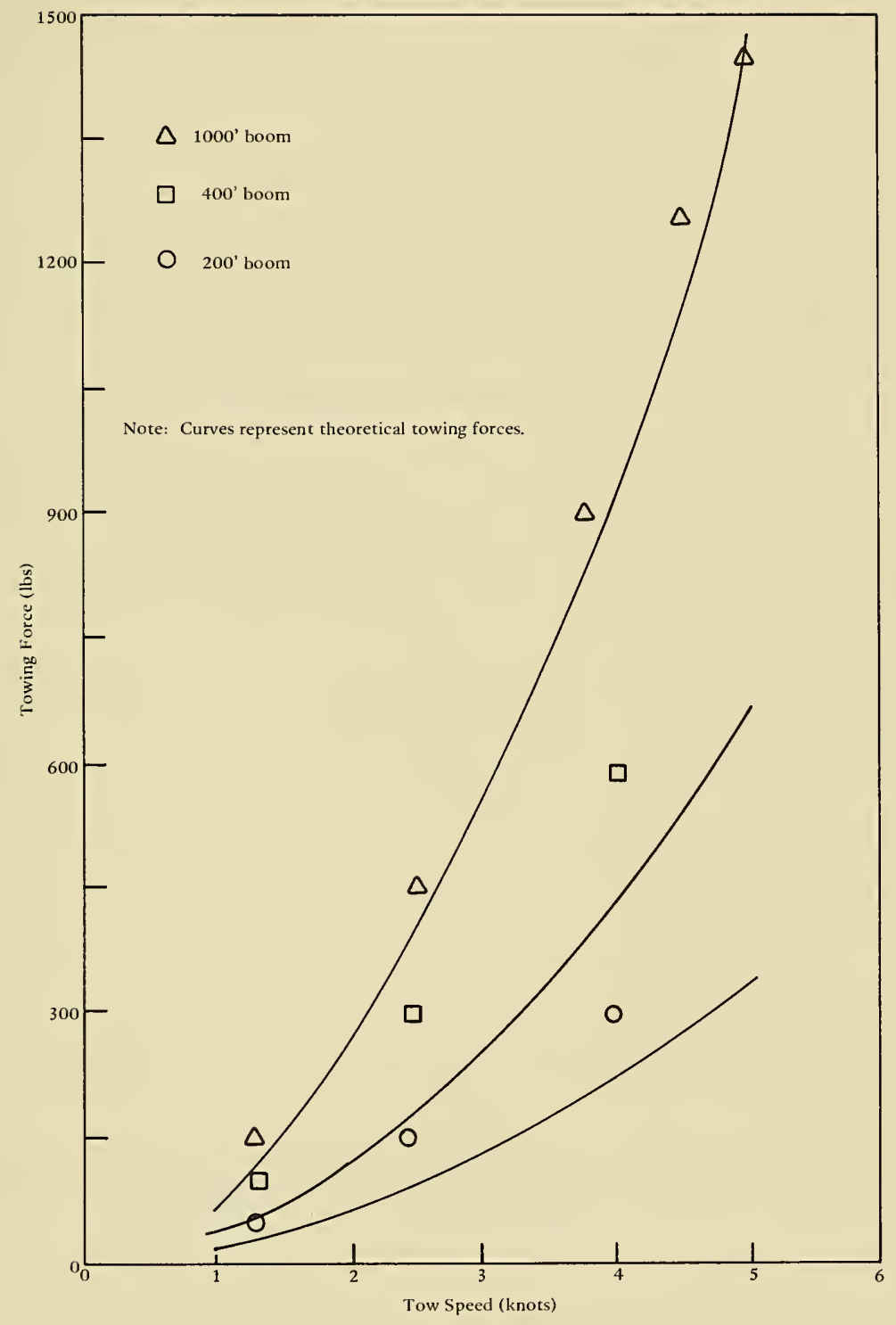

Figure 23. Straight-1ine towing forces* in oil boom.

* Theoretical forces calculated for $\mathrm{C}_{\mathrm{F}}$ of .0049 and boom height of 3 feet. 


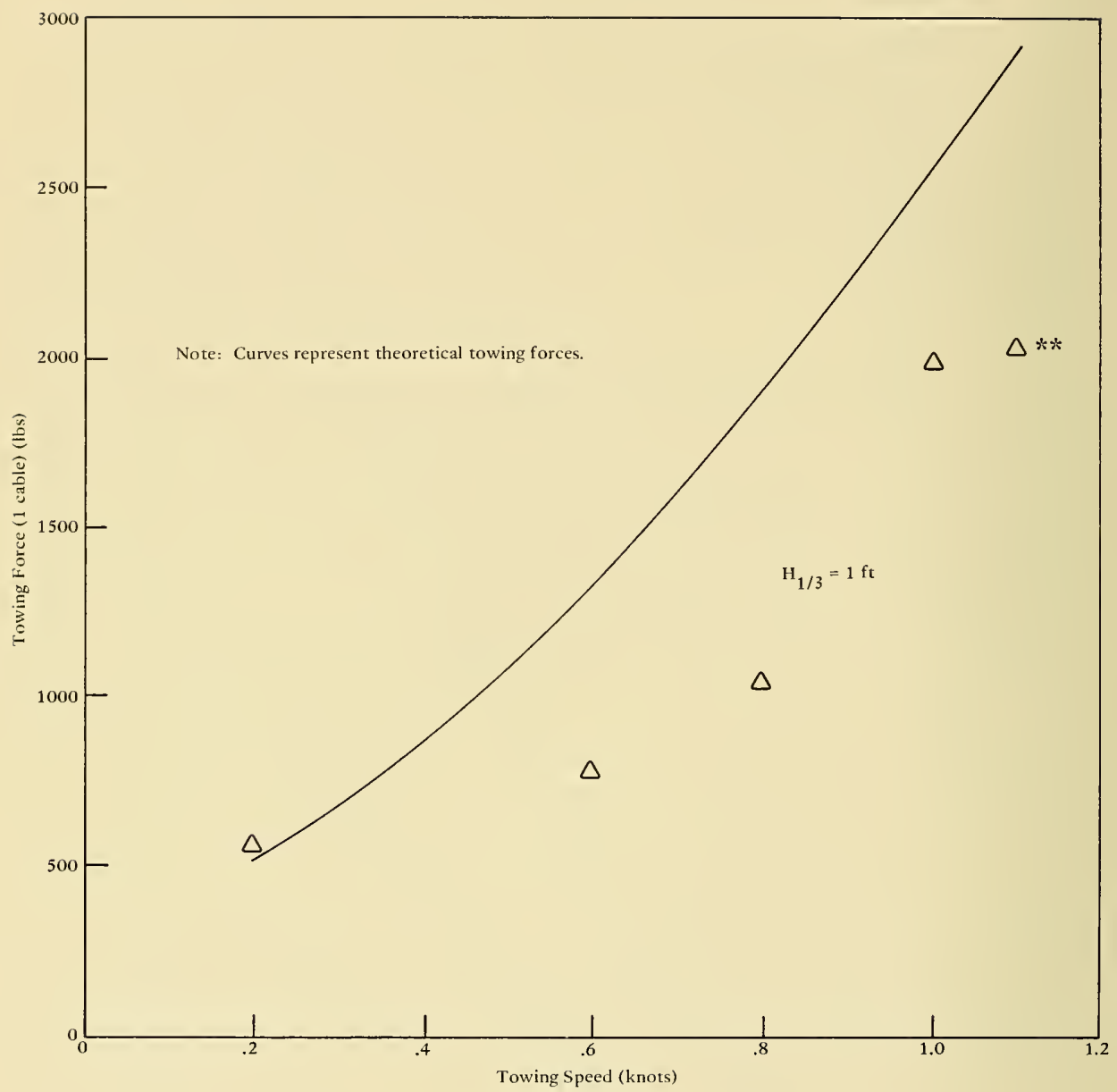

Figure 24. Catenary towing forces* in oil boom.

* Theoretical towing force was calculated assuming significant wave height $\mathrm{H}_{1 / 3}$ of 2 feet and catenary opening of 300 feet.

$* *$ Boom turned on its side. 
Table 1. Comparison of Proposed Designs of Boom Connectors

\begin{tabular}{|c|c|c|}
\hline Connector & Advantages & Disadvantages \\
\hline Figure 1A & $\begin{array}{l}\text { 1. Not susceptible to decoupling } \\
\text { from horizontal surge forces } \\
\text { acting along the boom. } \\
\text { 2. A certain amount of swivel } \\
\text { action possible. }\end{array}$ & $\begin{array}{l}\text { 1. Must slide full height } \\
\text { of boom during assembly } \\
\text { and disassembly. }\end{array}$ \\
\hline Figure 1B & $\begin{array}{l}\text { 1. Extruded shapes. } \\
\text { 2. Easier fabrication than } \\
\text { connector in Figure } 1 \mathrm{~A} \text {. } \\
\text { 3. Relatively insensitive to } \\
\text { accidental decoupling. }\end{array}$ & $\begin{array}{l}\text { 1. Must slide full height } \\
\text { of boom during assembly } \\
\text { and disassembly. } \\
\text { 2. No rotational freedom } \\
\text { about axis perpendicular } \\
\text { to the plane. }\end{array}$ \\
\hline Figure $1 \mathrm{C}$ & $\begin{array}{l}\text { 1. Two halves can be connected } \\
\text { without sliding their lengths } \\
\text { relative to each other. } \\
\text { 2. Connector marketed commer- } \\
\text { cially. }\end{array}$ & $\begin{array}{l}\text { 1. Vertical alignment for } \\
\text { installing the small } \\
\text { retaining pin through } \\
\text { both connector halves } \\
\text { may be difficult. } \\
\text { 2. Only the retaining pin } \\
\text { holds the sections } \\
\text { together and could fail } \\
\text { or be accidentally } \\
\text { pulled out or lost. } \\
\text { 3. Subject to decoupling } \\
\text { from wide variety of } \\
\text { surge forces always pre- } \\
\text { sent in the field in } \\
\text { event of pin failure. }\end{array}$ \\
\hline Figure 1D & $\begin{array}{l}\text { 1. Two halves can be attached } \\
\text { without sliding their lengths } \\
\text { relative to each other. }\end{array}$ & $\begin{array}{l}\text { 1. May prove difficult to } \\
\text { align in field. }\end{array}$ \\
\hline
\end{tabular}


Table 2. Comparison of Proposed Designs of the Towing Assembly

\begin{tabular}{|c|c|c|}
\hline $\begin{array}{c}\text { Towing } \\
\text { Assembly }\end{array}$ & Advantages & Disadvantages \\
\hline Figure 2A & $\begin{array}{l}\text { 1. Self-floating. } \\
\text { 2. Paravane counteracts the } \\
\text { vertical component of the } \\
\text { towline force. } \\
\text { 3. Roll damping plate. }\end{array}$ & 1. None. \\
\hline Figure 2B & $\begin{array}{l}\text { 1. More compact than that of } \\
\text { Figure } 2 \mathrm{~A} \text {. } \\
\text { 2. One end of boom connector } \\
\text { used as tow plate without } \\
\text { addition of paravane } \\
\text { foot. }\end{array}$ & $\begin{array}{l}\text { 1. Not self-floating. } \\
\text { 2. Flexibility of towing } \\
\text { bridles (could make it } \\
\text { difficult to attach under } \\
\text { field conditions). }\end{array}$ \\
\hline
\end{tabular}

Table 3. Comparison of Proposed Designs of Bulkhead Attachment

\begin{tabular}{|c|c|c|}
\hline Attachment & \multicolumn{1}{|c|}{ Advantages } & \multicolumn{1}{c|}{ Disadvantages } \\
\hline Figure 3 & $\begin{array}{l}\text { 1. Simple construction. } \\
\text { 2. Same structural components } \\
\text { as boom connector in Fig- } \\
\text { ure 1A. }\end{array}$ & 1. None. \\
Figure 4 $\begin{array}{l}\text { Rotational flexibility } \\
\text { about vertical axis, } \\
\text { minimizing bending loads } \\
\text { in tidal fluctuations. } \\
\text { 1. Already marketed commer- } \\
\text { cially. }\end{array}$ & $\begin{array}{l}\text { 1. Construction is more } \\
\text { complicated than that } \\
\text { of Figure 3. } \\
\text { Rotational flexibility } \\
\text { about the roller track } \\
\text { is quite limited. }\end{array}$ \\
\hline
\end{tabular}




\section{REFERENCES}

1. W. Pierson and L. Moskowite. Proposed spectral form for fully developed wind seas based on similarity theory of S. A. Kilagorodskii, Journal of Geophysical Research, vo1. 69, no. 24, Dec 1964, pp. 5181-5190.

2. E. Miller, et al. Experimental procedures used in the development of oil retention boom designs, Marine Technology, vol. 9, no. 3, July 1972, pp. 317-332.

3. R. J. Roark. Formulas for stress and strain. New York, N.Y., McGrawHil1, Inc., 4th Edition, 1965, p. 384.

4. Mark's standard handbook for mechanical engineers. New York, McGrawHi11, 6th Edition, 1958.

5. John J. Meyers. Handbook of ocean and underwater engineering. New York, McGraw-Hill, 1969, pp. 2-25. 
Appendix A

HYDRODYNAMIC FORCES

During field use, a boom assembly experiences forces resulting from the relative currents and wave action on the boom skirt and flotation and from wind action on the boom freeboard area.

In catenary tow, the hydrodynamic forces on the boom include the steady drag force caused by (1) the relative towing velocity and (2) the more complicated, unsteady surge and impact forces from the waves. Waves in an actual seaway are difficult to characterize in simple analytical form. Based on a statistical analysis, it is common to use the significant wave height of the one-third highest waves, $\overline{\mathrm{H}}_{1 / 3}$, * as the significant wave height for the irregular ocean waves. An energy spectrum found to correlate the irregular waves of the ocean is the Pierson-Moskowite spectrum [1]. This spectral description is used below to estimate the drag force on a boom under catenary tow.

For the straight-line tow, the drag force is estimated using the results for frictional drag, $F_{O}$, on a flat plate in turbulent flow.

\section{CATENARY TOW}

For a steady towing velocity the drag force on the skirt of the boom can be approximated by the relation for drag on a vertical flat plate, i.e.,

$$
\mathrm{F}_{\mathrm{O}}=1 / 2 \mathrm{C}_{\mathrm{D}} \rho \mathrm{v}^{2} \mathrm{hS}
$$

where

$$
\begin{aligned}
C_{D} & =\text { drag coefficient } \\
\rho & =\text { mass density of water }\left(\text { slug } / \mathrm{ft}^{3}\right) \\
\mathrm{v} & =\text { towing velocity }(\mathrm{ft} / \mathrm{sec}) \\
\mathrm{h} & =\text { skirt depth (ft) } \\
\mathrm{S} & =\text { catenary opening }(\mathrm{ft})
\end{aligned}
$$

For the total force including the effect of unsteady wave action, Miller, et al. [2] obtained an empirical relation for estimating the drag. The total drag force, $F_{D}$, on the boom skirt can be computed by the expression

* Significant wave height is determined by sampling the height of a population of waves over a given length of time, dividing the population into thirds by height, and then averaging the heights obtained for the highest one-third of the wave population. 
The connector was modeled as a simple supported beam carrying a distributed load. This model was considered to be a valid representation of actual loading configuration as existing oil booms have tension members (cables, chains, etc.) built into the top and bottom of their structure that can be considered to act as simple structural supports. The connector loading model is shown in Figure A-2. For conservative design calculations, the distributed load was converted to a point load located 12 inches from the bottom of the 36-inch, Type II boom. This converted model is shown in Figure A-3.

The transverse hydrodynamic load on the connector is highest at the center of a catenary. This load is computed assuming the load is equal to that from the drag forces acting on a flat plate. The pressure distribution on the submerged portion of the boom is of the general shape shown in Figure $A-1$. The drag force per square foot of the connector due to this pressure distribution is calculated using the formula

$$
\overline{\mathrm{F}}_{\mathrm{D}}=\mathrm{C}_{\mathrm{D}} \rho \frac{\mathrm{v}^{2}}{2}
$$

where $F_{D}=$ drag pressure $\left(1 \mathrm{~b} / \mathrm{ft}^{2}\right)$

$$
\begin{aligned}
C_{D} & =\text { drag coefficient } \\
\rho & =\text { mass density of water }\left(\text { slugs } / \mathrm{ft}^{3}\right) \\
\mathrm{v} & =\text { tow speed }(\mathrm{ft} / \mathrm{sec})
\end{aligned}
$$

The frontal area (A) of the connector assembly is $2.25 \mathrm{ft}^{2}$ for the largest Type II boom. The transverse hydrodynamic load or the drag force, on the connector assembly, is therefore

$$
F_{D} A=521 b
$$




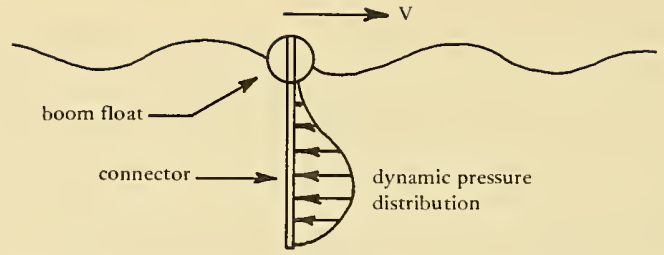

Figure A-1. Shape of the pressure distribution on the submerged portion of the boom.

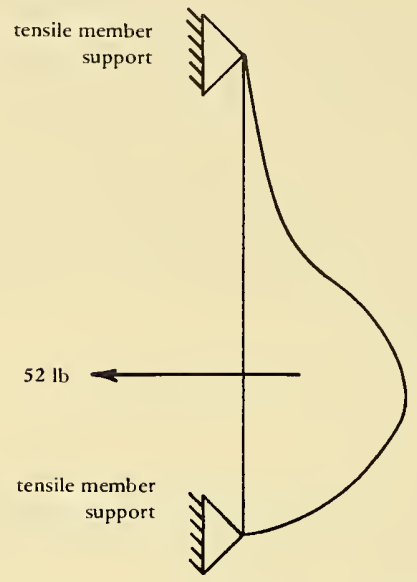

Figure A-2. Loading diagram.

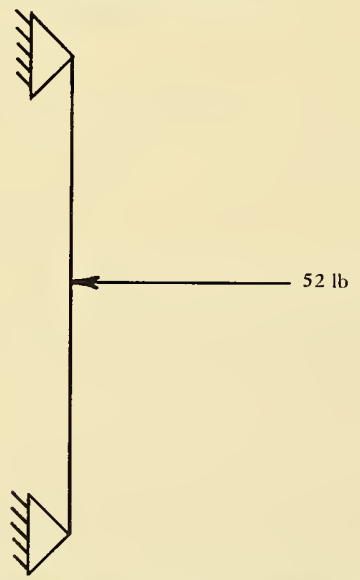

Figure A-3. Load model for sizing connectors. 


$$
F_{D}=F_{0}\left(1+0.59 \mathrm{C} \frac{\mathrm{H}_{1 / 3} \omega_{\text {max }}}{\mathrm{V}}\right)^{2}
$$

where

$$
\begin{aligned}
\mathrm{C}= & \text { empirical constant } \\
\omega_{\text {max }}= & \begin{array}{l}
\text { maximum frequency or maximum energy in wave } \\
\text { spectrum (rad/sec) equaling } 2.26 / \sqrt{\mathrm{H}_{1 / 3}} \text { for } \\
\\
\text { Pierson-Moskowite spectra }
\end{array} \\
\mathrm{V}= & \text { towing velocity (KT) } \\
\mathrm{H}_{1 / 3}= & \text { height of one-third highest waves }
\end{aligned}
$$

Assuming a Pierson-Moskowite spectra for the ocean and a value of $\mathrm{C}=0.23$ [2], Equation A-2 becomes

$$
F_{D}=F_{\circ}\left(1+0.308 \sqrt{\mathrm{H}_{1 / 3} / \mathrm{V}}\right)^{2}
$$

Added to this is the wind force, $\mathrm{F}_{\mathrm{W}^{\prime}}$ which is

$$
\mathrm{F}_{\mathrm{W}}=1 / 2 \mathrm{C}_{\mathrm{D}} \rho_{\mathrm{a}} \mathrm{v}_{\mathrm{a}}^{2} \mathrm{fS}
$$

where $\rho_{a}=\operatorname{density}\left(\operatorname{slug} / f t^{3}\right)$ of air

$\mathrm{v}_{\mathrm{a}}=$ wind velocity ( $\left.\mathrm{ft} / \mathrm{sec}\right)$

$\mathrm{f}=$ freeboard height $(\mathrm{ft})$

Taking $C_{D}=1.5$ and $\rho_{a}=0.00269 \mathrm{slug} / \mathrm{ft}^{3}$, Equation $\mathrm{A}-4$ becomes

$$
\mathrm{F}_{\mathrm{W}}=0.00576 \mathrm{fS} \mathrm{v}_{\mathrm{a}}^{2}
$$

$\mathrm{V}$ is now wind velocity in knots.

The total drag force on a length of boom in catenary tow is given by the sum of Equations $A-3$ and $A-5$. For a 1,000-foot length of boom in a catenary with a 500-foot opening these equations were used to obtain the force values in Table $\mathrm{A}-1$. Type I Class 1 (12 inch), Type I Class 2 (24 inch), and Type II (36 inch). 
For the straight-1ine tow boom towing configuration the force, $\mathrm{F}_{\mathrm{D}}$, acting on the boom, is given by the frictional drag on the skirt, i.e.',

$$
F_{D}=C_{F} \rho v^{2} h L
$$

$$
\text { where } \begin{aligned}
C_{\mathrm{F}} & =\text { friction coefficient } \\
\mathrm{h} & =\text { boom skirt depth (ft) } \\
\mathrm{v} & =\text { tow speed (ft/sec) } \\
\mathrm{L} & =1 \text { length of the boom (ft) }
\end{aligned}
$$

The value of $C_{F}$ is dependent on the Reynolds number, $R=V L / U$, where $U$ is the kinematic viscosity $\left(1.09 \times 10^{-5} \mathrm{ft}^{2} / \mathrm{sec}\right.$ for seawater). It is noted that for a 1,000-foot length of boom the value of the Reynolds number is over $10^{9}$ and the condition for straight tow is always turbulent.

In particular, at a tow speed of 10 knots, $R=1.6 \times 10^{9}$, $\mathrm{C}_{\mathrm{F}}=0.0015$, and Equation $\mathrm{A}-6$ yields

$$
\mathrm{F}_{\mathrm{D}}=854 \mathrm{~h}
$$

Equation A-7 was used to estimate the drag force on 1,000 feet of boom in a straight-line tow for each of the three boom types. The results are shown in Table $A-2$. It should be noted that the estimate given by Equation A-7 does not include the effects of unsteady forces caused by towing through the complex wave spectrum of an actual seaway. Limited data recorded in April 1972, during a field-acceptance test of boom of the same size as Type II indicated a towline force of 2,800 pounds when towing at 10 knots.

In any event, since the force loadings are much higher in catenary tow, they were used in the structural analyses described in Appendix $B$.

ANALYSIS OF TRANSVERSE HYDRODYNAMIC LOADS ON A BOOM CONNECTOR

For sound structural design the boom-end connectors must be sized to accommodate transverse hydrodynamic forces that are placed on the connectors when a boom is being towed in a catenary configuration (Figure A-1). A model that can be used in sizing connectors and an estimate of the magnitude of transverse hydrodynamic forces are determined below. Calculations are made for a connector located at the center of a boom catenary. 
Table A-1. Forces Acting on 1,000 Feet of Boom Under Catenary Tow

\begin{tabular}{|c|c|c|c|}
\hline \multirow{2}{*}{ Parameters } & \multicolumn{3}{|c|}{ Boom Types } \\
\hline & Type I, Class 1 & Type I, Class 2 & Type II \\
\hline Tow Speed, knots & 1 & 1.5 & 2 \\
\hline Wind Speed, knots & 15 & 20 & 25 \\
\hline Wave Height, feet & 0.416 & 0.75 & 1.0 \\
\hline Wind Force, pounds & 269 & 864 & 1,800 \\
\hline Drag Force, pounds & 2,231 & 9,823 & 25,390 \\
\hline Total Force, pounds & 2,500 & 10,700 & 27,200 \\
\hline Towline Force, pounds & 1,250 & 5,350 & 13,600 \\
\hline
\end{tabular}

Table A-2. Forces Acting on 1,000 Feet of Boom in Straight Tow

\begin{tabular}{|l|c|c|c|}
\hline \multirow{2}{*}{ Parameters } & \multicolumn{3}{|c|}{ Boom Types } \\
\cline { 2 - 4 } & Type I, Class 1 & Type I, Class 2 & Type II \\
\hline Tow Speed, knots & 10 & 10 & 10 \\
Skirt Depth, feet & 0.667 & 0.333 & 2.0 \\
$\begin{array}{l}\text { Total Drag Force, } \\
\text { pounds }\end{array}$ & 570 & 1,140 & 1,700 \\
\hline
\end{tabular}


Using the force loadings determined in Appendix A, the candidate designs for the boom connector, tow assembly, and bulkhead-attachment assembly were analyzed structurally to determine component size for 6061T6 aluminum.

\section{BOOM CONNECTOR}

Structural calculations for the boom connectors included sizing the connector to withstand tensile loads along the boom, and transverse bending loads. The clamping area required to secure the boom end to the connector was also determined.

The structural analysis procedure applied to each of the four candidate connectors of Figure 1 is outlined below. For purposes of conservative design, the tensile force loads appearing in Table A-1 for the Type II boom were used to size each of the candidate connectors. Connector crosssections sized for these loads can be used for the smaller booms and still provide adequate strength when subjected to smaller loads that occur when Type I, Class 1 and 2 booms are used. Extrusions of 6061T6 aluminum with a modulus, $\mathrm{E}$, of $10 \times 10^{6} \mathrm{psi}$ and a yield strength of 35,000 psi were used for all calculations. The procedure used to determine connector size required to withstand tensile and transverse loads is outlined below.

1. Assume a nondimensional connector configuration from Figure 1.

2. Determine connector dimensions such that it will withstand the tensile load created by Type II boom as shown in Table A-1.

3. Determine the cross-sectional moment inertia required of the connector and its associated clamping plate to withstand transverse hydrodynamic loads.

4. Adjust the cross-sectional dimensions of connector and clamping plate to produce a moment of inertia equal to required moment of inertia developed in step 3 above.

The analysis outlined above is applied to the first candidate in the following discussion.

The maximum tensile load on the connector occurs during catenary tow. Using the load estimate for Type II boom from Table A-1, each towline exerts a tensile force of 13,600 pounds on the connector assemblies 
close to the towed ends. The plate thickness, b, of the first candidate connector (shown in Figure B-1A) necessary to accept this load without failure is given by

$$
\mathrm{b}=\frac{\mathrm{F}}{\sigma \ell}
$$

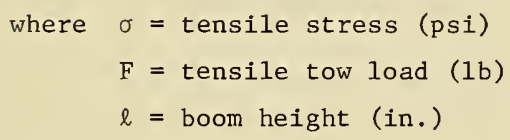

Using a maximum allowable stress of 35,000 psi, a tow load of 13,600 pounds, and a boom height of 36 inches, Equation B-1 yields a required thickness of

$$
\mathrm{b}=0.037 \text { inch }
$$

This calculation indicates that a very thin plate could be used if it were subjected to a pure static tensile load of 13,600 pounds. However, stress concentrations created by the presence of holes and attachment of primary tension members occur in practice which would require an increase in thickness over this value. From Reference 3 the stress-concentration factor for a hole one diameter away from the edge of a plate is about 3.6. A plate thickness of 0.25 inch, instead of 0.037 inch, is used in the remaining calculations, resulting in a safety factor of about 6.8 which should allow for the stress-concentration factors mentioned above.

The maximum stress on the large connector tube (see Figure B-1A) due to a tensile tow load occurs on the outside edge. The size of the tube wall is determined using the free-body diagram of Figure $\mathrm{B}-1 \mathrm{~B}$. From equilibrium considerations of this diagram, the wall thickness, $t$, is determined from the equation

$$
\sigma=\frac{F}{l t}\left(3.5+3 \frac{R}{t}\right)
$$

where the symbols are as defined for Equation B-1 or indicated in Figure B-1A.

Using the same values as used in Equation B-1 the wall thickness is given by Equation $\mathrm{B}-2$ to be

$$
t=0.36 \text { inch }
$$


To determine what reinforcing was necessary to prevent transverse bending of the connector, some assumptions were made about the applied load. The connector was assumed to be a simply supported beam subjected to a point load of 52 pounds as shown in Figure B-2C (see Appendix A for details of this calculation).

The greatest stress occurs at the outside fiber of the beam at point $A$ as indicated in Figure $B-2 B$. The required moment of inertia about the neutral axis of the connector and any necessary reinforcing is given by

$$
I=\frac{M c}{\sigma}
$$

where $M=$ maximum bending moment in the connector

$c=$ outer radius of the connector tube (in.)

$\sigma=$ allowable stress (psi)

Inserting the values of these variables as determined in Appendix A the required moment of inertia, I, to prevent exceeding the allowable stress is

$$
I=0.46 \text { in. } .^{4}
$$

The moment of inertia of the connector, using the dimensions of Figure $\mathrm{B}=1 \mathrm{~A}$, is

$$
I=1.12 \mathrm{in.} .^{4}
$$

and no additional reinforcing is necessary.

Similar computations were made for the other connector candidates. Dimensions for these are shown in Figure $B-2$.

Figure B-3 shows schematically the clamping and connector plates as they would be attached to a boom end. The connector plate has holes to accept the primary tension members (e.g., cable or chain) of a boom of a particular vendor. The boom end has a rod embedded in the fabric to assist in preventing the boom fabric from being torn loose by the tension force, $\mathrm{T}$.

In order to conservatively size the width of the clamping plate, the friction force developed by clamping the fabric between two pieces of aluminum was assumed to be the only force available to keep the fabric from being pulled from between the two aluminum pieces. The required magnitude of this force can be calculated from Equation B-4 below which relates the width of the clamping plate to the force required per inch of height of the fabric. 


$$
\mathrm{T}=2 \mu \mathrm{P}_{B} \mathrm{~W}
$$

where $\mu=$ coefficient of friction between fabric and metal

$\mathrm{P}_{\mathrm{B}}=$ clamping pressure provided by the bolts (psi)

$\mathrm{W}=$ width of clamping channe1 (in.)

$\mathrm{T}=$ tensile load over boom height (lb/in.)

From Reference 4, the tensile load, F, in pounds that can be imposed on a bolt by hand tightening of a nut can be approximated by

$$
\mathrm{F}=16,000 \times \text { (bolt diameter, inch) }
$$

Therefore, for 3/8-inch-diameter bolts the approximate load is 6,000 pounds. Using a bolt spacing of 3.5 inches to maintain a nearly uniform clamping pressure results in an "influence area"' of 9.65 inches square and a clamping pressure, $P_{B}$, of about 625 psi for each bolt.

Typical values of $\mu$ range from 0.04 (Teflon on stee1) to 0.61 (leather on oak). Assuming a value for $\mu$ of 0.10 and the value of $P_{B}$ given above, Equation B-4 becomes, after solving the width, W,

$$
W=\frac{T}{125}
$$

As shown in the hydrodynamic drag calculations of Appendix A, the maximum tensile load occurs for the Type II boom in a catenary tow. With the assumption that $50 \%$ of this 1 oad will be carried by the fabric and $50 \%$ by the primary tension members, the resulting vertical loading, $\mathrm{T}$, is $190 \mathrm{lb} / \mathrm{in}$. of fabric. Inserting this value of $\mathrm{T}$ in Equation B-5 gives a maximum required clamping channel width of

$$
\mathrm{W}=1.5 \text { inches }
$$

Therefore, to assure that the fabric boom is not pulled out of the connector, a clamping plate at least 1.5 inches wide using $3 / 8$-inch bolts on 3.5 -inch centers is required.

\section{TOWING ASSEMBLY}

A serviceable towing assembly must be rigid enough to resist the bending and buckling loads that will occur in field service, must still be able to maintain the boom in a vertical attitude, and must provide a proper towing load distribution over the vertical boom end. 
The tow assembly design of Figure $2 \mathrm{~A}$ was analyzed for structural adequacy and for performance using the force loading diagram of Figure $B-4$. Figure $B-4 A$ is a diagram of forces on the entire assembly, and Figure $\mathrm{B}-4 \mathrm{~B}$ is a free body diagram of the vertical member to which the boom is attached. This is the member most likely to fail under the loads encountered during field use.

Referring to Figure B-4A, expressions can be written for the vertical and horizontal force components and solved for the unknown paravane area, A, (an inclined flat plate) by eliminating the towline force, $\mathrm{F}_{\mathrm{T}}$. The resulting expression is

$$
A=\frac{2\left(F_{B}+F_{D}\right)}{\rho v^{2} C_{D}\left(\sin ^{2} \alpha \cos \alpha \frac{\cos \theta}{\sin \theta}-\sin ^{3} \alpha\right)}
$$

where $F_{B}=$ tension force exerted by boom (1b)

$F_{D}=$ drag force of tow assembly alone (1b)

$\rho=$ mass density of water $\left(\mathrm{s} l u g / \mathrm{ft}^{3}\right)$

$\mathrm{v}=$ tow speed (ft/sec)

$\mathrm{C}_{\mathrm{D}}=$ drag coefficient for flat plate

$\theta=$ towline angle

$\alpha=$ paravane angle

The highest straight line tensile tow force occurs when Type II boom is towed at 10 knots. In this case, the tensile tow load, $F_{B}$, is estimated from Appendix A to be 2,800 pounds. The estimated drag force of the assembly itself was calculated to be 254 pounds. Using these values and a towline angle of 5 degrees, a paravane angle of 55 degrees, and a flat-plate drag coefficient of 1.28 [5], the paravane area, A, necessary to counteract the vertical component of the towline force is

$$
A=2.2 \mathrm{ft}^{2}
$$

The required areas for Type I, Class 1 and Type I, Class 2 would, of course, be smaller. The paravane angle of 55 degrees was chosen to maximize the terms involving $\alpha$ in Equation B-6. Changing the towline angle 5 to 10 degrees increases the vertical towline force component and increases the required paravane area to $5.1 \mathrm{ft}^{2}$. Thus, for the paravane to be effective, a small towline angle (long scope on towline) is essential. 
For a catenary tow at 2 knots, the largest forces occur with the Type II boom. Using the tensile load of 13,600 pounds, from Table A-1 and the same data for angles and drag coefficient as above, the required area, A, becomes

$$
\mathrm{A}=244 \mathrm{ft}^{2}
$$

Thus a realistic paravane is clearly inadequate to counteract the vertical component of the towline force for Type II boom at the low speed of 2 knots. For the smallest Type I Class 1 boom in a catenary tow the required area is $2.7 \mathrm{ft}^{2}$. Keeping the towed boom end from rising up under the action of the vertical force component and then lying over is more important in the catenary sweep mode than in the straightline tow since only in the catenary sweep mode is oil being contained. Since the paravane areas determined for this operating mode are quite large, even for the sma11 Type I Class 1 boom, it was decided that no paravanes were to be used and this mode of failure avoided by maintaining as long a scope as is necessary to prevent the boom end from being pulled out of the water to an unstable roll condition.

The structural analysis of the tow assembly is based on the freebody diagram of Figure B-4A. The vertical strut of Figure B-4B is considered as a beam rigidly supported at its ends with the uniform load, $F_{B}$, along its length. The equation for deflection at the center of such a beam is

$$
\mathrm{Y}_{\max }=\frac{1}{384}\left(\frac{\mathrm{F}_{\mathrm{B}} \ell^{3}}{\mathrm{EI}}\right)
$$

where $\mathrm{Y}_{\max }=$ maximum deflection at center of beam span (in.)

$\mathrm{F}_{\mathrm{B}}=$ load imposed by boom (1b)

$\ell=$ length of strut (in.)

$\mathrm{E}=$ modulus of elasticity (psi)

$I=$ area moment of inertia of beam cross section (in. ${ }^{4}$ )

In addition, the maximum fiber stress on the outer surface of the strut due to the applied bending load, $F_{B}$, is given by

$$
\sigma_{\max }=\frac{F_{B} \text { lC }}{24 I}
$$

where $\sigma_{\max }=$ maximum fiber stress in strut

$C=$ distance from neutral axis to outer surface of strut 
Eliminating $\mathrm{F}_{\mathrm{B}}$ between Equation $\mathrm{B}-9$ and Equation $\mathrm{B}-10$ results in an expression for the maximum deflection, $\mathrm{Y}_{\max }$, associated with the given maximum stress, $\sigma_{\max }$, for a given material.

$$
Y_{\max }=\frac{24}{384}\left(\frac{\sigma_{\max ^{\ell}}}{\mathrm{CE}}\right)
$$

The maximum allowable design stress for $6061-\mathrm{T} 6$ aluminum is $\sigma_{\max }=$ $35,000 \mathrm{psi}$. Assuming, as before, a design safety factor of 3.5 , the maximum stress used in Equation B-11 is 10,000 psi. Setting the value of $l=36$ inches, $E=10 \times 10^{6} \mathrm{psi}$, and $\mathrm{C}=2.5$ inches, the maximum deflection is

$$
\mathrm{Y}=0.009 \text { inches }
$$

which is quite acceptable for the functional aspects of the tow assembly design. Inserting $\mathrm{Y}_{\max }$ into Equation $\mathrm{B}-9$ or using Equation $\mathrm{B}-10$ directly, the required strut cross-section moment of inertia, $I$, can be found to be $I=5.1 \mathrm{inch}^{4}$. This moment of inertia value is achieved if the dimensions of Figure $B-4 B$ are: $r_{0}=1.1$ inch, $r_{i}=0.74$ inch, $t=0.5$ inch, and $l=2.5$ inches. To check for the possibility of buckling of the strut when under tow, the maximum allowable compressive end load for the particular strut is calculated. From Reference 3, the relation for the maximum end load for column buckling is

$$
\mathrm{P}_{\max }=18,000-120 \frac{\ell}{\mathrm{K}}
$$

$$
\text { where } \begin{aligned}
P_{\max } & =\text { maximum end load (psi) } \\
\ell & =\text { length of column (in.) } \\
k & =\text { radius of gyration (in.) }
\end{aligned}
$$

Using the dimensions of the column strut as determined above the resulting end load for buckling is

$$
P_{\max }=14,580 \mathrm{psi}
$$

The cross-sectional strut area is 2.98 in. ${ }^{2}$, so the compressive load required to buckle the tow assembly strut is over 43,000 pounds. Since the total tow load as estimated in Table A-1 never exceeds 14,000 pounds, failure of the strut by buckling is highly unlikely. 


\section{BULKHEAD ATTACHMENT}

The bulkhead attachment candidates were analyzed structurally for their ability to withstand the tensile and bending loads indicated in Figures 3 and 4.

Referring to Figure 3, if the dimensions for the split tube sliding track are the same as for the first boom connector candidate discussed in this Appendix, the assembly can safely carry the full Type II boom tensile tow load appearing in Table A-1. Using a free-body diagram similar to that employed for the boom connector calculations, it can be determined that the point of maximum stress in the assembly of Figure 3 when subjected to bending loads occurs at the outer diameter of the sliding track near the support angle. To maintain the design safety factor of 3.5 , this maximum stress must be held to $10^{4} \mathrm{psi}$. The maximum allowable bending load, directed perpendicular to the tensile load shown in Figure 3 , is calculated to be 1,740 pounds, which should be sufficient because the bulkhead attachment will be used in harbor situations where the currents and boom lengths are relatively low. It should be noted that from Table A-1 for 1,000 feet of Type I Class 1 boom (which is the type most likely to be used with the bulkhead attachment) the towline force is 1,250 pounds, or almost 500 pounds less than necessary for a design safety factor of 3.5 .

The design candidate of Figure 4 was studied in the same manner as described above. It was found that under a pure tensile load of 13,600 pounds (see Table A-1) a plate thickness of 0.019 inch was required for the roller assembly. As in the design candidate of Figure 3 , the more strict structural requirements were derived from the bending loads the assembly would experience with fluctuating tidal currents. If the plate thickness of the roller assembly is 0.25 inch, the maximum allowable bending load is calculated to be 1,500 pounds, similar to the allowable design load for the candidate of Figure 3. The roller track is quite rigid, and will support the full 13,600-pound bending load with a flange 0.25 inch thick by 2 inches wide. 

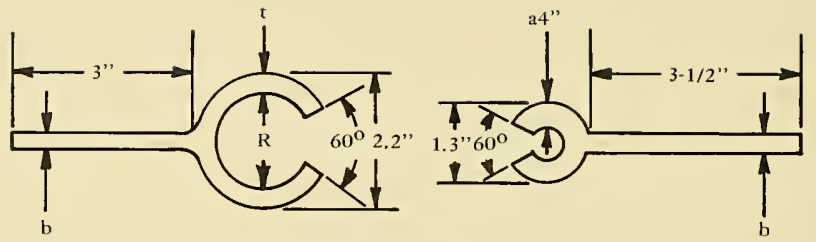

(A)
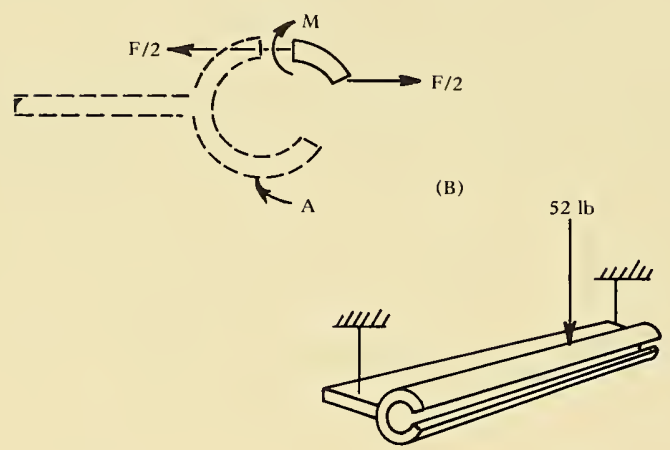

(C)

Figure $\mathrm{B}-1$. Boom connector loading. 

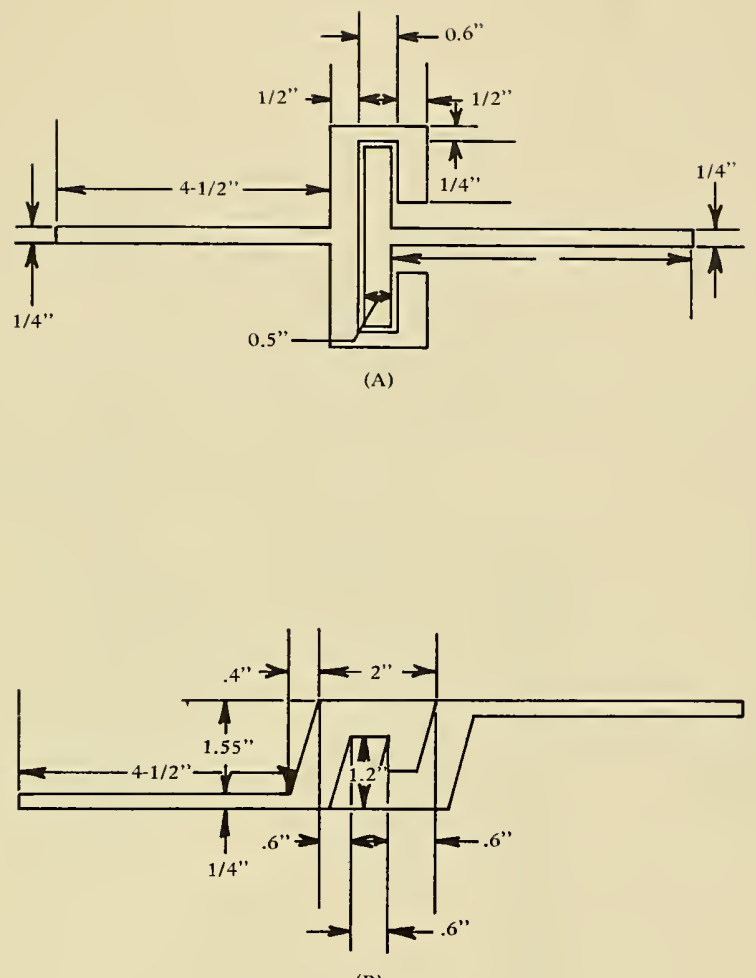

(B)

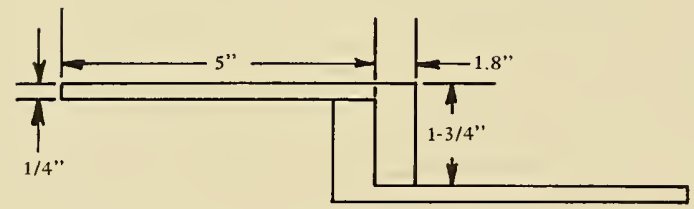

(C)

Figure B-2. Structural sizing of candidates. 


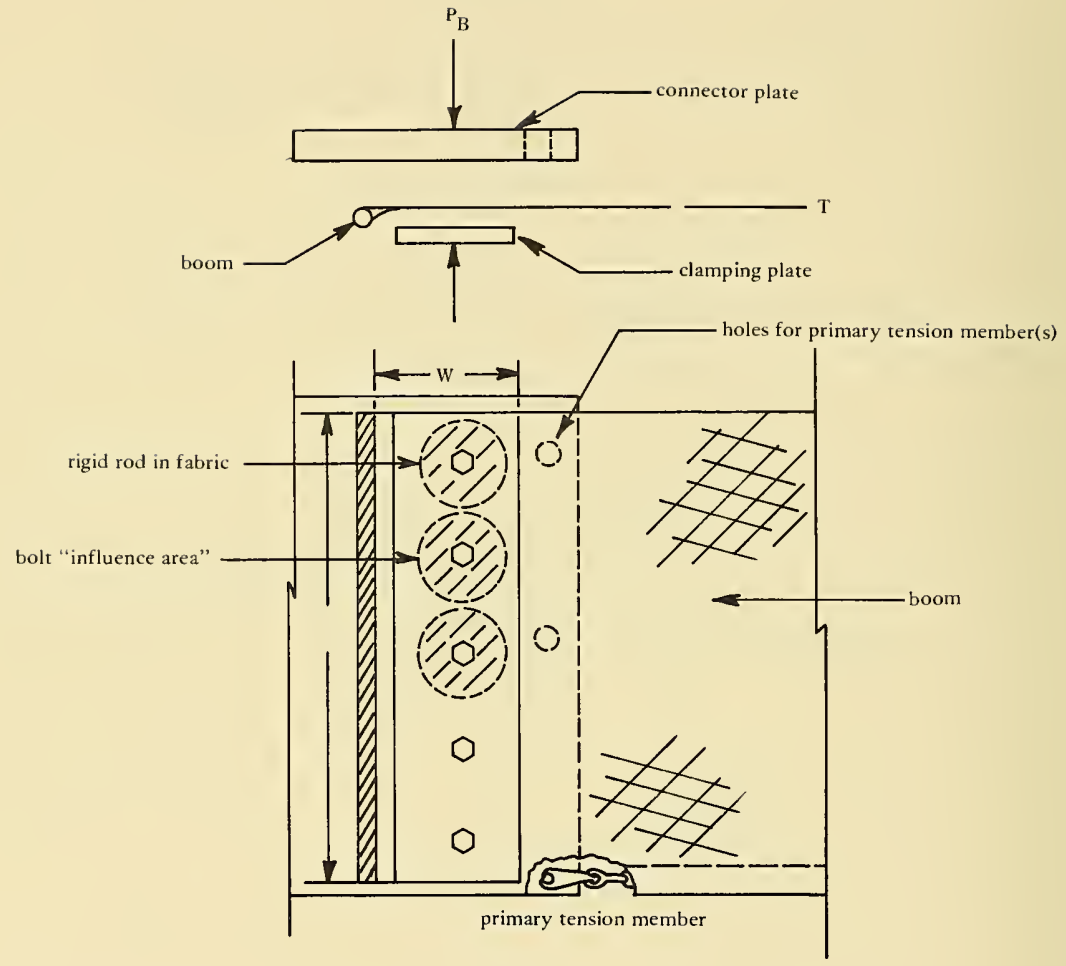

Figure B-3. Boom-end clamping detail. 


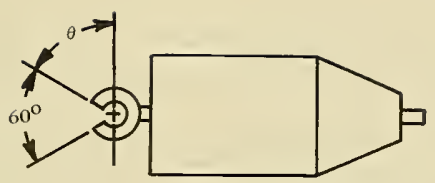

(a) Towing assembly.

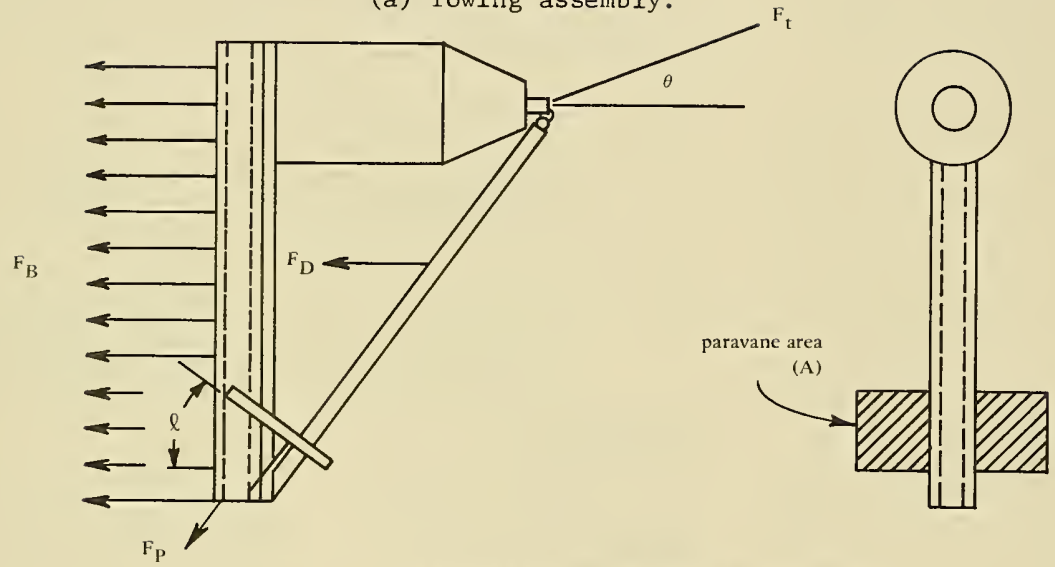

(b) Vertical boom attachment member.
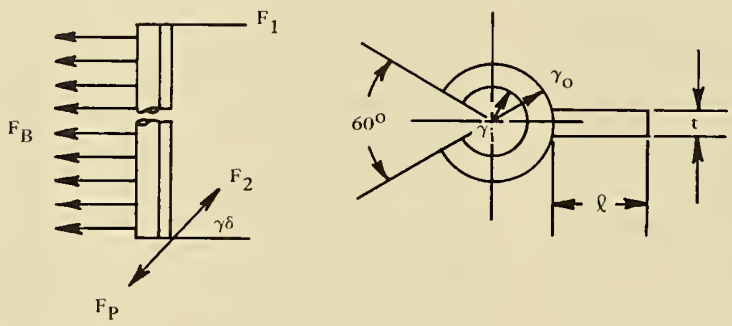

Figure B-4. Towing assembly loading diagrams. 


\section{DISTRIBUTION LIST}

$\begin{array}{ccc}\begin{array}{c}\text { SNDL } \\ \text { Code }\end{array} & \begin{array}{c}\text { No. of } \\ \text { Activities }\end{array} & \begin{array}{r}\text { Total } \\ \text { Copies }\end{array} \\ \text { FKAIC } & 1 & 12 \\ \text { FKNI } & 6 & 60 \\ \text { FKN5 } & 9 & 9 \\ \text { FA25 } & 1 & 1 \\ --- & 9 & 9\end{array}$

Defense Documentation Center

30 Naval Facilities Engineering Command

$6 \quad$ NAVFAC Engineering Field Divisions

9 Public Works Centers

1 Public Works Center

9 RDT\&E Liaison Officers at NAVFAC

Engineering Field Divisions and

Construction Battalion Centers

364

364

CEL Special Distribution List No. 9

for persons and activities interested in reports on Environmental Engineering (R\&D for pollution control)

AFCRL; $\times O L$

L. G. Hanscom Field

Bediord, MA 01730

Natick Labs

Kansas St.

Natick, MA 01761

Public Works Officer

Boston Naval Shipyard

Boston. MA 02129

M. B. Graham
Boston Naval Shipyard

Boston Naval Shipyard
Boston, MA 02129

Bernard Willey (Code 385 )

Boston Naval Shlpyard

Boston, MA 02129

Public Works Officer

Naval Hospltal, Boston

Chelsea, MA 02150

Public Works Officer

Naval Air Station
South Woymoutin, MA 02190

LCDR David A. Cacchione, USN Office of Naval Rosearch, Broff 495 Summer Street Boston, MA 02210
Mr. S. Milligan

SB 322

Naval Underwater Systems Center Newport, RI 02844

Naval Station

495 Summer Street

Boston, MA 02210

Public Works Officer

Naval Underwater Systems Center Newport, RI 02844

Public Works Officer
Naval Facility
Nantucket, MA 02554

Commancino officer

Commanding Officer

Commanding Officer
CBC Technical Library
Naval Construction Battaion Center

Naval Construction Battaion Center
Davisville, Ri 02854 (2 copies)

Naval Air Station

Library

Cold Regions Research \& Eng. Lab. P. O. Box 282

Hanover, NH 03755

Commanding Officer (Code 200)

Navy Public Works Center

Newport, RI 02840

Commanding Officer

Naval Supply Depot

Newport, Ri 02840

Public Works Officer

Portsmouth Naval Shipyard

Portsmouth Naval Shipy

President

Navat War College

Code 22
Newport, Rl 02840

Public Works Officer

U.S. Naval Disciplinary Command

Portsmouth, NH 03801

Commanding Offlcer

U.S. Naval Station

Newport, Ri 02840

Public Works Officer

Naval Air Station

Brunswick, ME 04011

Staff Clvil Engineer

Nava) Supply Center

Newport, Ri 02840
Public Works Officer

East Machias, ME $04630^{\circ}$
Naval Radio Station (T), Cutler

* All Addrasseas receivo one copy unless otherwise Indicated. 
Public Works Officer

Naval Security Group Activity

Winter Harbor, ME 04693

Public Works Department

Box 400

Naval Submarine Base, New London

Groton, CT 06340

Commanding General

U. S. Army Electronics Command

Attn: AMSEI-GG-TO

Fort Monmouth, NJ 07703

Engineering Director

Code 092

Naval Ammunition Depot, Earle

Colts Neck, NJ 07722

Pastics Technical Evaluation Center

SMUPA-VP3

Picatinny Arsenal

Dover. NJ 07801

Public Works Officer

Naval Air Propulsion Test Center

Trentom, NJ 08628

Public Works Officer

Naval Air Station

Lakenurst, NJ 08733

Commander
$20 t n$ Naval Construction Regiment

$20 t n$ Naval Construction
FPO New York 09501

Commanding Officer

Mobile Construction Battalion 74

FPO New York 09501

Operations Officer

Mobile Construction Battalion 40

FPO New York 09501

Commanding Officer

Amphibious Construction Battation TWO

FPO New York 09501

Public Works Officer

G.S. Naval Activities, United Kingdom

Public Works Officer

U.S. Naval Activities, United Kingdom Det.

Public Works Officer

U.S. Naval Support Activity

FPO New York 09521

Public Works Office

U. S. Naval Aur F acility

FPO New York 09523

Public Works Officer

U. S. Naval Communication Station

FPO New York 09525
Public Works Officer

Naval Control of Shipping Office

APO New York 09526

Public Works Officer

U. S. Naval Support Activity

PO New York 09585

Public Works Officer

U. S. Naval Medical Research Unit No. 3

FPO New York 09527

Public Works Officer

U.S. Navy Fleet Support Office

FPO New York 09532

LT Ronald A. Milner, CEC, USN

U. S. Naval Station

Public Works Officer

Morocco-U. S. Naval Training Command

Box 19

FPO New York 09544

Public Works Officer

U. S. Naval Communication Station

Box 41
FPO New York 09544

Public Works Officer

U.S. Navy Support Activity

FPO New York 09550

Public Works Officer

U.S. Naval Station

FPO New York 0955

Commanding Officer

U.S. Naval Hospital

FPO New York 0955

Public Works Officer

U. S. Naval Facility

FPO New York 09552

Public Works Officer

U.S. Naval Communication Station

FPO New York 09554

Public Works Officer

F.S. Naval Security Group Activity

Public Works Officer

U. S. Naval Facility

Public Works Officer

F. S. Naval Air Station

Public Works Officer

U. S. Naval Station

FPO New York 09571

Public Works Offlcer

U. S. Naval Communication Station

FPO New York 09580
Public Works Officer

U. S. Naval Station

Box 25

FPO New York 09593

Staff Civil Enqinee

U. S. Naval Air Station

Box 35-D

FPO New York 09593

Public Works Office

U. S. Naval Station

FPO New York 09597

Public Works Officer

U. S. Naval Communication Station

APO New York 09843

Public Works Officer, Naval Station

136 Flushing Avenue

Brooklyn, NY 11251

Public Works Officer

Naval Strategic Systems Navigation Facility

Flushing \& Washington Avenue

Brooklyn, NY 11251

Public Works Officer

U. S. Naval Hospital

St. Albans, LI, NY 11425

Public Works Officer

Naval Ships Parts Control Center

Mechanicsburg, PA 17055

Public Works Officer

Naval Air Development Center

Warminster, PA 18974

Public Works Officer

Naval Air Station

Willow Grove, PA 19090

Commanding Officer

Code $016 \mathrm{~A}$

Northern Divisıon

Naval Facilities Engineering Command

Philadelphia, PA 19112

RDT \&E Liaison Officer

Code 102 Northern Division

Naval Facilities Engineering Command

Philadelphia, PA 19112

Public Works Officer

Philadelphia Naval Shipyard

Philadelphia, PA 19112

Commanding Officer

Naval Station

Philadelphia, PA 19112

Public Works Officer

Naval Air Engineering Center

Philadelphia, PA 19112 
Public Works Dfficer

Naval Hospital

7 th Street \& Pattison Avenue

Philadelphia, PA 19145

Public Works Officer

National Naval Medical Center

Bethesda, MD 20014

\section{Mr. R. B. Allnutt}

Code 1706

Naval Ship Research \& Development Center Bethesda, MD 20034

Head Facilities \& Industrial Department

Code 54

Carderock Laboratory

Naval Ship Research \& Development Center Bethesda, MD 20034

William F. Gerhold

National Bureau of Standards

Corrosion Section

Washington, DC 20234

A. Maillar

Maritime Administration

Office of Ship Construction

washington, DC 20235

Defense Civil Preparedness Agency

ATTN: RE (SR), Mr. George N. Sisson

Room 1D538, Pentagon

Washington, DC 20301

Mr. Neal Fitzsimons

Defense Civil Preparedness Agency (RE/SE)

Room 1D538, Pentagon

Washington, DC 20301

Dr. James O. Buchanan

Defense Civil Preparedness Agency

Washington, DC 20301

Chief of Engineers

U. S. Army

Washington, DC 20314

$A F / R D P Q$

Washington, DC 20330

Benj. R. Petrie, Jr

Op-987T 8; Staff Director RDT \&E

Room 4B514, Pentagon

Room 48514 , Pentagon
Washington, DC 20350

Commander

Naval Suppiy Systems Command

Headquarters

SUP 0423

Washington, DC 20360

Technical Library, Ships 2052

Naval Ship Systems Command

National Center No. 3

Washington, DC 20362

Commander
Naval Ship Systems Command

Code 00

Washington, DC 20362

Mr. David L. Southey

Code $41 \mathrm{~A}$

Bureau of Medicine and Surgery

Navy Department

Washington, DC 20372
Chief

Bureau of Medicine \& Surgery

Research Departmen

Navy Department

Washington, DC 20372

U.S. Naval Oceanographic Office

Library - Code 3600

Washington, DC 20373

John DePalma

Code 9233

U.S. Naval Oceanographic Office

Washington, DC 20373

Director

Naval Research Laboratory

Code 262

Washington, DC 20375

Mr. J. J. Gennari

Naval Research Laboratory

Code 8410

Washington, DC 20375

Public Works Officer

Naval Research Laboratory

4555 Overlook Ave. SW

Washington, DC 20375

Commanding Officer

Chesapeake Division - Code 03

Naval Facilities Engineering Command

Washington Navy $\mathrm{Y}$ ard

Washington, DC 20390

CDR L. K. Donovan, CEC, USN

Chesapeake Division

Naval Facilities Engineering Command

Washington Navy Yard

Washington, DC 2039

Public Works Officer

Washington, DC 20390

Commandant

Naval District Washington

Public Works Department - Code 412

Washington, DC 20390

Public Works Officer

Naval Security Station

3801 Nebraska Avenue, NW

Washington, DC 20390

Naval Security Engineering Facility Technical Library

3801 Nebraska Avenue, NW

washington, DC 20390

Public Works Officer

Naval Communication Station

Washington, DC 20390

Mr. M. R. Whitley

Criteria \& Research Branch

Office of Construction Management

General Services Administration

Washington, DC 20405

General Services Administration

Federal Supply Service (FMSB)

Washington, DC 20406

Commandant (MMT-4)

U. S. Coast Guard

$400 \mathrm{SW} 7$ th Street

Washington, DC 20590
Mr. Willard Lawall

U. S. Coast Guar

Office of Engineering (E/64)

400 SW 7 th Street

Washington, DC 20590

Public Works Officer

Naval Ordnance Station

indian Head, MD 20640

Public Works Officer

Naval Air Station

Patuxent River, MD 20670

Technical Library

Naval Ship Engineering Center

622 Center Bldg

Prince Georges Center

Hyattsville, MD 20782

$\mathrm{Mr}$. John B. Alfers

Naval Ship Engineering Center

Code $6101 \mathrm{E}$

Prince Georges Center

Hyattsville, MD 20782

Chief

Marine \& Earth Sciences Library

National Dceanic \& Atmospheric Admin.

Dept of Commerce

Rockville. MD 20852

M. E. Ringenbach

Engineering Development Lab (C61)

National Dceanic \& Atmospheric Admin.

National Ocean Survey
Rockville, MD 20852

Public Works Office

Naval Ordnance Laboratory. White Oak

Code 942

Silver Spring, MD 20910

Mr. H. A. Perry

Naval Drdnance Laboratory, White Dak

Silver Spring. MD 20910

Commanding Office

ATTN: STEAP-T

Bldg 305
Aberdeen Proving Ground, MD 21005

Army Environmental Hygiene Lab.

Edgewood Arsenal, MD 21010

LCDR Robert D. Smart, CEC, USN

Naval System Engineering Dept

U. S. Naval Academy

Annapolis, MD 21402

Director

Division of Engineering \& Weapons

U. S. Naval Academy

Annapolis, MD 21402

Dr. Neil T. Monney

Naval Systems Engineering Dept

U. S. Naval Academy

Annapolis, MD 21402

Library, Code 5642

Annapolis Laboratory

Naval Ship Research \& Dev. Center 
Public Works Officer Naval Support Facility

Box 277

Thurmont, MD 21788

Public Works Department

Naval Training Center

Bainbridge, MO 21905

Commanding officer

ATTN: SMEFB-HPC (Mr. Cevasco)

U.S. Army Mobility Equip. R\&D Center

Fort Belvoir, VA 22060

U.S. Army Coastal Eng. Research Center

R. A. Jachowsk

Kingman Buildin

Fort Belvoir, VA 22060

Public Works Officer

Marine Corps Dev. \& Education Command

Quantico, VA 22134

\section{Director}

Development Center

Marine Corps Dev. \& Education Command

Quantico, VA 22134

Facilities Officer

Office of Naval Research

Code 108

800 North Quincy St ree

Arlington, VA 22217

\section{Dr Nicholas Perrone}

Code 439

Office of Naval Research

800 North Quincy Street

Arlington, VA 22217

Oceanographer of the Navy

ATTN: Code N7 1

200 Stovall Street

Alexandria, VA 22332

CAPT Pharo A, Phelps, CEC, USN

Naval Facilities Engineering Command 2005 tovall 5 treet

Alexandria, VA 22332

\section{Commander}

Code $0436 \mathrm{~B}$

Naval Facilities Engineering Command

200 Stovall Street

Alexandria, VA 22332

\section{Commander}

Code 102

Naval Facilities Engineering Command

200 Stovall St ree

Alexandría, VA 22332

CDR Walter J. Eager, CEC, USN

Code PC-2

Naval Facilities Engineering Command

200 Stovall Stree

Alexandria, VA 22332

Public Works officer

Naval Weapons Laboratory

Dahlgren, VA 22448

Public Works Officer

Fleet Combat Direction Systems

Training Center, Atlantic

Dam Neck

Virginia Beach, VA 23461

Public Works Officer

Naval Weapons Station
Commanding Office

avy Public Works Center

Norfolk, VA 23511

Staff Civil Engineer

Naval Air Station

Norfolk, VA 23511

Commander

Code $10 \mathrm{~A}$

Atlantic Division

Naval Facilities Engineering Command

Norfolk, VA 23511

RDT\&E Liaison Officer

Code 09P2

Atlantic Division

Naval Facilities Engineering Command

Norfolk, VA 23511 (2 copies)

Staff Civil Engineer

Commander Service Force

U.S. Atlantic Fleet

Norfolk, VA 23511

Public Works Officer

Naval Amphibious Base, Little Creek

Norfolk, $\vee A 23521$

General Enginee

Naval Hospital

Portsmouth, VA 23708

Director

Engineering Division - Code 440

Public Works Department

Norfolk Naval Shipyard

Portsmouth, VA 23709

Commandant

U. S. Army Logistics Management Center

DLSIE

Fort Lee, VA 23801

Public Works Officer

Naval Facility, Cape Hatteras

Buxton, NC 27920

Public Works Office

Marine Corps Air Station

Cherry Point. NC 28533

Public Works Office

Marine Corps Air Station, New River

Jacksonville, NC 28540

Public Works Office

Naval Hospital

Camp Lejeune, NC 28542

Public Works officer

Marine Corps Base

Camp Lejuene, NC 28542

Chief Enginee

Naval Weapons Station

Charleston, SC 29408

Public Works Officer

Charleston Naval Shipyard

Naval Base

Charieston, SC 29408
Staff Civil Engineer

Naval Hospital

Charleston, SC 29408

Public Works Officer

Naval Station

Naval Base

Charleston, SC 29408

RDT \& E Liaison Office

Southern Division - Code 90

Naval Facilities Engineering Comman P. O. Box 10068

Charleston, SC 29411

Staff Civil Engineer

Naval Supply Center

Charleston, SC 2941

Public Works Officer

Naval Hospital

Beaufort, SC 29902

Public Works Officer

Marine Corps Air Station

Beaufort, SC 29902

Public Works Office

P. O. Box 35

Marine Corps Recruit Depo

Parris Island, SC 29905

Public Works Office

Naval Air Station, Atlanta

Marietta, GA 30063

Public Works Department

Naval Air Station

Giynco, GA 31520

Public Works Office

Albany, GA 31703

Public Works Office

Marine Corps Supply Center

Albany, GA 31704

Director of Engineering

Naval Air Station

Jacksonville, FL 32212

Public Works Officer

Naval Air Station

Cecil Field, FL 32215

Public Works Office

Naval Station

Mayport, FL 32228

AFCEC/DE

Tyndatl Air Force Base, FL 32401

Public Works Offıce

Naval Coastal Systems Laboratory

Panama City, FL 3240 
Staff Civil Engineer

Pensacola, FL 32508

Commanding Officer (Code 200) Navy Public Works Center, Bldg 1 Naval Air Station

Pensacola, FL 32508

Public Works Officer

Naval Air Station, Whiting Field

Milton, FL 32570

Public Works Officer

Naval Training Cente

Orlando, FL 32813

Staff Civil Engineer

Naval Training Equipment Center

Orlando, FL 32813

Public Works Officer
Naval Security Group Activity

Homestead, FL 33030

Public Works Officer

Naval Station

Key West, FL 33040

Staff Civil Engineer

Naval Air Station

Key West, FL 33040

AUL/SE-63-465

Maxwell Air Force Base, AL 36112

Public Works Officer

Naval Air Station. Memphis (84)

Millington, TN 38054

Staff Civil Engineer

Naval Hospital Memphis

Millington, TN 38054

Library Branch

Army Engineer Waterways Experiment station

Vicksburg, MS 39180

Public Works Officer

Naval Air Station

Meridian, MS 39301

Public Works Dept. (Code 400)

Naval Construction Battalion Center

Gulfport, MS 39501

Public Works Officer

Naval Ordnance Station

Louisville, KY 40214

AFIT

Civil Engineering School

Wright-Patterson AFB, OH 45433
Public Works Officer

Indianapolis, in 46218

Public Works Officer

Naval Ammunition Depot

Crane, IN 47522

Public Works Officer

Naval Air Facility Detroit

Mount Clements, Mi 48043

Army Construction Eng. Research Lab.

ATTN: Library

Champaign, IL 61820

Commanding Officer - Engineering Div.

MRD-Corps of Engineers

D. O. Box 103 . Downtown Station

Omaha, NE 68101

Chief, Engineering Division

U. S. Army Engineer District (Omaha)

Corps of Engineers

6012 U. $\$$. Post Office \& Courthouse

Omaha, NE 68102

Resident Officer in Charge of Construction Naval Support Activity, Fort Ömaha

30 th and Fort Streets

Omaha, NE 68111

Public Works Department

Maintenance Division

Naval Air Station. New Orleans

Belle Chasse, LA 70037

Public Works Officer

Naval Air Station, New Orleans

Belle Chasse, LA 70037

Public Works Officer

Naval Ammunition Depot

McAlester, OK 74501

Public Works Officer

Naval Air Station

Dallas, $T \times 75211$

Public Works Officer

Storage Facility

Orange, $T \times 77630$

Public Works Officer

Naval Air Station

Chase Field

Beeville, TX 78102

AF Environmental Health Lab.

Kelly AFB, TX 78241

Public Works Officer

Naval Air Station

Corpus Christi, TX 78419

Public Works Department

Marine Corps Air Station

Yuma, AZ 85364
Technical Reference Division Fort Huachuca, AZ 85613

AFWL

CE Division

Kirtland AFB, NM 87117

Public Works Office

Naval Air Station

Fallon, NV 89406

Publlc Works Officer

Naval Ammunition Depot

Hawthorne, NV 89415

Public Works Officer

Naval Air Station

Los Alamitos, CA 90720

Public Works Officer

Naval Weapons Station

Seal Beach, CA 90740

Public Works Office

Naval Station

Long Beach, CA 90801

Public Works Department

Code 400

Long Beach Naval Shipyard

Long Beach, CA 90801

Dr Arthur R. Laufer

Office of Naval Research, BROFF

1030 East Green Street

Pasadena, CA 91106

Asst. Public Works Officer

Naval Weapons Station

Fallbrook Annex

Fallbrook, CA 92028

Staff Civil Engineer

Naval Air Station

Imperial Beach, CA 92032

Public Works Officer

Marine Corps Base

Camp Pendleton, CA 92055

Technical Library

Code 1311

Naval Undersea Center

San Diego, CA 92132

Director

San Diego Branch

Western Division

Naval Facilities Engineering Command

San Diego, CA 92132

Public Works Officer

Public Wor 75

Code 75 ork

Naval Undersea Center
San Diego, CA 92132

Staff Civil Enginee

Naval Training Cente

San Diego, CA 92133 
Public Works Officer

Naval Administrative Command

Naval Training Center

San Diego, CA 92133

Civil Staff Enginee

Nava! Hospital

San Diego, CA 92134

Public Works Officer

Naval Air Station

North Islan

San Diego, CA 92135

Commander Naval Air Force

Box 1210

U. S. Pacific Freet

Naval Air Station. North Island

San Diego, CA 92135

Staff Civil Engineer

Naval Station

San Diego, CA 92136

Commanding Dfficer

Navy Public Works Center

Naval Base

San Diego, CA 92136

Public Works Officer

Naval Air Station

Mirama

San Diego, CA 92145

Public Works Officer

Naval Amphibious Base

Coronado

San Diego, CA 92155

Public Works Officer

Naval Air Facility

Ei Centro, CA 92243

Public Works Officer

Marine Corps Base

Marine Co

Twentynine Palms, CA 92278

Public Works Officer

Marine Corps Supply Center

Barstow, CA 92311

U.S. Marine Corps Air Station Attn: Public Works Dept (Code 150)

El Toro

Santa Ana, CA 92709

Commanding Officer

Naval Missile Center

Code 5632.2. Technical Library

Point Mugu, CA 93042

Office of Patent Counsel

Code PC (BOX 40)

Naval Missile Center

Point Mugu, CA 93042

Public Works Officer

Naval Air Station

Point Mugu, CA 93042

\section{Public Works Officer}

Code 82

Naval Construction Battalion Center

Port Hueneme, CA 93043
Librarian, Code 9215

Construction Equioment Department

Naval Construction Battalion Center

Port Hueneme, CA 93043

Commanding Officer

Code 155

Naval Construction Battalion Center

Port Hueneme, CA 93043

Technical Library - Code C 35

Naval School Civil Engineer Corps Officers

Bldg 44

Port Hueneme, CA 93043

Commander (Code 753)

Technical Library

Naval Weapons Center

China Lake, CA 93555

Public Works Officer (70)

Naval Weapons Center

China Lake, CA 93555

Public Works Officer

Naval Facility, Big Sur

Big Sur, CA 93920

Superintendent

Attn: Library (Code 2124

Naval Postgraduate School

Monterey, CA 93940

Public Works Officer

Public Works Dept

Naval Postgraduate School

Monterey, CA 93940

Public Works Officer

Naval Air Station

Moffett Field, CA 94035

Commanding Of ficer

Western Division - Code 09PA

Naval Facilities Engineering Command

707

San Bruno, CA 94066

Commanding Officer

Western Division. Code of

Naval Facilities Engineering Comman P. O. Box 727

San Bruno, CA 94066

Commanding Office

Western Division - Code 04B

Naval Facilities Engineering Command P. O. Box 727

San Bruno, CA 94066

Commanding Officer

Western Oivision. Code 05

Naval Facilities Engineering Commano

P. D. Box 727

San Bruno, CA 94066

Commanding Office

Western Division - Code 111

Naval Facilities Engineering Comman Naval Facilities

San Bruno, CA 94066

Commanding Officer

Western Division - Code 09Pg

Naval Facilities Engineering Command

P. O. Box 727

San Bruno, CA 94066

Public Works Officer

Naval Station

Treasure islan o

San Francisco, CA 94130
Asst Resident OIC of Construction Bldg 506

Hunters Point Naval Shipyard

San Francisco, CA 94135

Public Works Dfficer

San Francisco Bay Naval Shipyard

San Francisco, CA 94135

Public Works Department (183)

Naval Air Station

Alameda, CA 94501

Mr. John R. Saroyan

Code 134.5

Mare Island Naval Shipyard

vallejo, CA 94592

Public Works Officer

Mare Island Naval Shipyard

vallejo, CA 94592

Asst. Public Works Officer

Naval Support Activity

Mare Island Naval Shipyard

vallejo, CA 94592

Public Works Officer

Code 70

Naval Supply Center

Oakland, C.A 94625

Public Works Officer

Naval Hospital

Oakland, CA 94627

Public Works Officer

Naval Communication Sta. San Francisco

Rough and Ready Island

Stockton, CA 95203

Public Works Olficer

Naval Facility, Centerville Beach

Ferndale, CA 95536

AF Environmental Health Lab

McClellan AFB, CA 95652

Public Works Officer

Headquarters Support Activity

Box 26

APO San Francisco 96263

Base Civis Engineer

Det 3 , 15th ABW (PACAF)

APOS

Engineering \& Planning Department Officer in Charge of Construction Naval Facilities Engineering Command Contracts

APD San Francisco 96346

Director, Engineering Division

Officer in Charge of Construction

Naval Facilities Engineering Command

Contracts, South west Pacific
APO San Francisco 96528

Headquarters

$K$ wajalein Missile Range

Box 26. Attn: SSCR-RKL-C

APO San Francisco 96555 
Commanding Officer

Mobile Construction Battalion TEN

FPO San Francisco 96601

Staff Civil Engineer

Pearl Harbor Naval Shipyard

Box 400

FPO San Francisco 96610

Staff Civil Engineer

Naval Supply Center

Box 300

FPO San Francisco 96610

Commander Pacific Division

Naval Facitities Engineering Command

FPO San Francisco 96610

ROT\&E Liaison Officer

Pacific Division. Code 403

Naval Facilities Engineering Command

FPOSan Francisco 96610

Mr. T. M. Ishibashi

Navy Public Works Center

Engineering Department - Code 200

FPO San Francisco 96610

Staff Civil Engineer

Naval Supply Center

Box 300

FPO San Francisco 96610

Mr. Melvin Miller

Code 703

Naval Supply Center

Box 300

FPO San Francisco 96610

Public Works Officer

U.S. Naval Air Station

FPO San Francisco 96611

Public Works Officer

Engineering Division

Naval Ammunition Depot

FPO San Francisco 96612

Public Works Officer

U. S. Naval Station

$\mathrm{Box} 15$

FPO San Francisco 96614

Public Works Officer

U.S. Marine Corps Air Station

F.S. Marine Corps Air Stancisco 96615

Staff Civil Engineer

U. S. Naval Communication Station

FPO San Francisco 96630

Staff Civil Engineer

U.S. Naval Station

FPO San Francisco 96630

Officer in Charge of Construction

Naval Facilities Engineering Command

Contracts Marianas

FPO San Francisco 96630

Staff Civil Engineer

U.S. Naval Station

FPO San Francisco 96630
Technical Library

Engineering Department

$U$. S. Navy Public Works Center

Box 6

FPO San Francisco 96651

Staff Civil Engineer

U.S. Naval Station

FPO San Francisco 96651

Public Works Office

Freet Activities

FPO Seattle 98770

Staff Civil Engineer

U.S. Naval Station

FPO San Francisco 96654

Public Works Officer

Marine Corps Air Station $(H)$

FPO Seattie 98772

Asst. Public Works Officer $\quad$ Public Works Officer

Box 1585

FPO San Francisco 96656

Public Works Officer

U.S. Naval Communication Station

Fí San Francisco 96680

Officer in Charge of Construction

Naval Facilities Engineering Command

Contracts

FPOSan Francisco 96680

U.S. Naval Support Force Antarctica

Detachment 1

FPO San Francisco 96690

Public Works Orficer

Naval Facility

Coos Head Empire Station

Coos Bay, OR 97420

Public Works Officer

Naval Support Activity

Seattle, WA 98115

Public Works Officer

Naval Air Station

Whiley Island

Oak Harbor, WA 98277

Public Works Dept., Code 400

Puget Sound $\mathrm{N}$ aval Shipyard

Bremerton, WA 98314

Public Works Office

Naval Torpedo Station

Keyport. WA 98345

Public Works Officer

Naval Facility, Pacific Beach

Pacific Beach, WA 98571

Commanding Officer

U.S. Navy Public Works Center

$\mathrm{BO} \times 13$

FPO Seattle 98762

Director Engineering \& Planning

$\mathrm{H} \& \mathrm{HS}$ bublic Works

Marine Corps Air Station

Marine Corps Air St

Commanding Officer

U. S. Naval Air Facility

Box 15

FPO Seattle 98767
Public Works Officer

U. S. Naval Station

FPO Seattle 98791

Public Works Office

U.S. Naval Communication Station Box 30

FPO Seattle 98791

Colleges, etc

Prof. W. E. Heronemus

Civil Engineering Dept.

University of Massachusetts

Amherst, MA 01002

MIT Libraries

Technical Reports - Room 14 E-210 Massachusetts Institute of Technology Cambridge, MA 02139

Mrs. A. P. Richards

Biological Sciences

William F. Clapp Labs - Battelle

Washington Street

Duxbury, MA 02332

Document Library L0-206

Woods Hole Oceanographic Institution woods Hole, MA 02543

Kline Science Library

Kline Biology Tower, Room C-8

Vale University

New Haven, CT 06520

Mr. Willard J. Piers on

University Institute of Oceanography

c/o The Bronx Community College

West 181 st St. \& University Ave.

Bronx, NY 10453

Reprint Custodian

Dept. of Nautical Science

U. S. Merchant Marine Academy

Kings Point, NY 11024

Dept of Civil Engineering

State University of New York

At Buffalo

Butfalo, NY 14214

Dr. Houan Yeh

Towne School of Civil \& Mech. Eng.

University of Pennsylvania

Philadelphia, PA 19104

Professor $E$. Chesson

132 DuPont Hall

Newark, DE 1971 
Mr. T. W. Mermel

Washington, D.C. 20016

Division of Medical Sciences National Academy of Science 2101 Constitution Avenue, NW Washington, DC 20418

Library of Congress

Science \& Technology Division

Washington, DC 20540

Research Library

Chesapeake Bay Institute

Chesa peake Bay Institute
The John Hopkins University

Battimore, MO 21218

W. F. Searle, Jr.

National Academy of Engineering

808 Timber Branch Parkway

Alexandria, VA 22302

Library

Virginia Institute of Marine Science

Gloucester Point, VA 23062

Public Documents Department

Wm. R. Perkins Library

Ouke University

Durnam. NC 27706

Dr Bruce Muga

Dept of Civil Engineering

Duke University

Duke University
Durham, NC 27706

Director

Oceanographic Program

Ouke University Marine Laboratory

Beaufort, NC 28516

Directo

Institute of Marine 5 ciences

Morehead City. NC 28557

Chairman

Department of Oceanography

Florida State University

Talahassee, FL 32306

Dr W. M. McLellon

Dept CEES

Box 25000

Florida Technological University

Orlando, FL 32816

Or. Charles E. Lane

Institute of Marine Science

University of Miami

Coral Gables, FL 33146

Dr R. F. McAllister

Professor of Oceanography

Florida Atlantic University

Boca Raton, FL 33432

Library

P. O. Box 5130

Madison, WI 53705

Lorenz G. Straub Memorial Library

St Anthony Falls Hydraulic Laboratory

Mississippi River at 3 rd Ave, 5 E

Minneapolis, MN 55414
Or R. C. Jordan

Dept of Mechanical Engineering

University of Minnesota

Minneapolis, MN 55455

Library

Portland Cement Association

Research \& Oevelopment Laboratories 5420 Old Orchard Road

Skokie, IL 60076

Metz Reference Room

Civil Engineering Oept

B106 Civil Engineering Bldg

University of Illinois

Urbana, IL 61801

Mr. G. A sutton

Planning \& Oevelopment

State Highway Commission

State office BIdg

Topeka, KS 66612

Acquisition Dept - Serials Section

University of Nebraska Libraries

Lincoln, NE 68508

Robert D. Tent

Undersea Services Oivision

Fluor Ocean Services Inc

P. O. Orawer 310

Houma, LA 70360

Oepartment of Oceanography

Texas A \& $M$ University

College Station, $T \times 77843$

Civil Engineering Dept

Texas A \& $\mathrm{M}$ niversit

Texas A \& M University

R. C. Dehart

Southwest Research Institute

8500 Culebra Road

San Antonio, TX 78228

Director

Institute of Marine Science

The University of Texas

Port Aransas, TX 78373

Professor M. M. Ayoub

Dept of IE

Texas Technological University

Lubbock, TX 79409

Wang Civil Engineering Research Facility

Wang Civil Engineering
P. O. BOx 188 - CERF

University Station

University Station

University of New Mexico

Or Bernard C. Abbott

Allan Hancock Foundation

University of Southern California

Los Angeles, CA 90007

\section{Oirector}

Catalina Marine Science Center

University of Southern California

Los Angeles, CA 90007

Aerospace Corporation

Acquisitions Group

P. O. Box 92957

Los Angeles, CA 90009

TRW Systems
Attn: P. K. Dai R1/2178

15 pace Park

15 pace Park
Redondo Beach, CA 90278
Mr. C. C. Mew

The Rand Corporation

1700 Main Street

Santa Monica, CA 90401

Mr. Frank Steiger

Port of Los Angeles Testing Laboratory

P. O. Box 786

Wilmington, CA 90741

Keck Reference Room (107-78)

136 W. M. Keck Laboratory

California Institute of Technology

Pasadena, CA 91109

Oceanic Library \& Information Center

$\mathrm{P} . \mathrm{B}$. 2369

La Jolla, CA 92037

Or John F. Peel Brantz

P. O. BOX 825

La Jolla, CA 92037

Mr. F. Simpson

Lockheed Ocean Laboratory

3380 No. Harbor Blvd
San Diego, CA 92101

Dr F. N. Spiess

Marine Physical Laboratory of the

Scripps Institution of Oceanography

University of California

Uan

Or. Victor C. Anderson

Marine Physical Laboratory of the

Scripps Institution of Oceanography

University of California

San Diego, CA 92151

CAPT H. L. Murphy, RET

593 Hawthorne Avenue
San Bruno, CA 94066

Engineering Library

Stanford University Libraries

stanford, CA 94305

Kenneth Kaplan

URS Research Company

155 Bavet Road

San Mateo, CA 94402

Mr. Richard G. Luthy

615 Madison $5 t$.

Albany, CA 94706

Engineering Library

University of Californi

Berkeley, CA 94720

Director

Calif. Dept of Navigation \& Ocean Develop.

14169 th Street

Sacramento, CA 95814

H. Norby Neilsen

University of Hawail
Honolulu, HI 96822 
School of Oceanography

Corvallis, OR 97331

Dept of Civil Engineering

University of Washington

Seattle, WA 98195

Dr S. R. Murphy

University of Washington

Seattie, WA 98195

\section{Oocuments}

University of Alaska Library

Fairbanks, AK

Alaska Water Laboratory

Environmental Protection Agency

College, AK 99701

\section{Director}

Ocean Engineering Program Offic

Naval Facilities Engineering Command

200 Stovall Street

Alexandria, VA 22332

Mr. Edmund Spencer

Ocean Engineering Program Office

Naval Facilities Engineering Command

200 Stovall Stree

Alexandria, VA 22332

Commanding Officer

Southern Division

Naval Facilities Engineering Command

P.O. Box 10068

Charleston, SC 29411 

